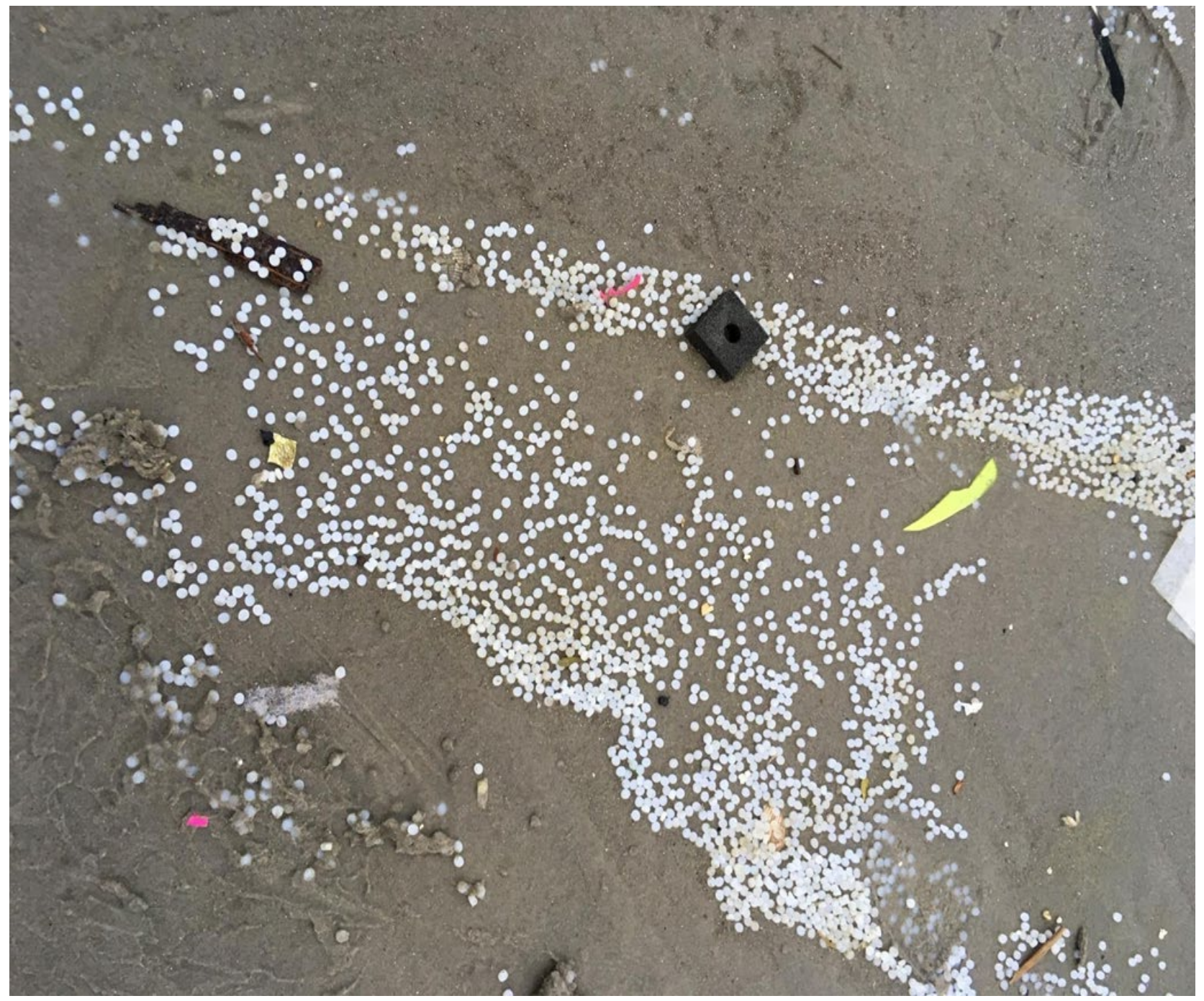

\title{
Inventarisatie aspecten rondom opruimen microplastics na maritieme incidenten
}




\section{Inventarisatie aspecten rond opruimen microplastics na maritieme incidenten}


Keywords: kustverontreiniging, pellets, strand, kwelder, dijk

Opdrachtgever: Rijkswaterstaat

T.a.v.: Mareike Erfeling

Postbus 2232

3500 GE Utrecht

Dit rapport is gratis te downloaden van https://doi.org/10.18174/558084

Wageningen Marine Research verstrekt geen gedrukte exemplaren van rapporten.

Wageningen Marine Research is ISO 9001:2015 gecertificeerd.

Foto omslag: Plastic pellets op het vloedmerk van het strand van Schiermonnikoog in januari 2019. Jan Willem Zwart (Natuurmonumenten)

(c) Wageningen Marine Research

Wageningen Marine Research, instituut binnen de rechtspersoon Stichting Wageningen Research, hierbij vertegenwoordigd door Drs.ir. M.T. van Manen, directeur bedrijfsvoering

KvK nr. 09098104, WMR BTW nr. NL 8113.83.696.B16. Code BIC/SWIFT address: RABONL2U IBAN code: NL 73 RABO 0373599285
Wageningen Marine Research aanvaardt geen aansprakelijkheid voor gevolgschade, noch voor schade welke voortvloeit uit toepassingen van de resultaten van werkzaamheden of andere gegevens verkregen van Wageningen Marine Research. Opdrachtgever vrijwaart Wageningen Marine Research van aanspraken van derden in verband met deze toepassing.

Alle rechten voorbehouden. Niets uit deze uitgave mag weergegeven en/of gepubliceerd worden, gefotokopieerd of op enige andere manier gebruikt worden zonder schriftelijke toestemming van de uitgever of auteur. 


\section{Inhoud}

Samenvatting

Summary

$1 \quad$ Inleiding

1.1 Aanleiding

6

1.2 Samenwerking Kustverontreiniging Maritieme Incidenten

1.3 Kennisvraag en doelstelling

1.4 Werkwijze

2 Achtergrond informatie

2.1 Container incidenten met plastics

2.2 Effecten van plastic pellets op soorten en ecosystemen

3.1 Handmatig harken

3.2 Handmatig zeven

3.3 Handmatig stofzuigen

3.4 Gemotoriseerd stofzuigen

3.5 Klassieke 'Beach cleaners'

4 Ecologische impact van opruimacties

4.1 Strand

4.2 Getijdenplaten

4.3 Kwelder

4.4 Harde dijk

$\begin{array}{lll}7.1 & \text { Meest effectieve opruimtechniek } & 24\end{array}$

$\begin{array}{lll}7.2 & \text { Ecologische effecten van opruimen } & 24\end{array}$

$\begin{array}{lll}7.3 & \text { Opruim en respons strategie } & 24\end{array}$

$\begin{array}{lll}7.4 & \text { Samenwerking } & 25\end{array}$

$\begin{array}{llr}7.5 & \text { Kennishiaten } & 25\end{array}$

8 Dankwoord $r 26$

$\begin{array}{llr}9 & \text { Kwaliteitsborging } & 27\end{array}$

$\begin{array}{lr}\text { Literatuur } & \mathbf{2 8}\end{array}$

$\begin{array}{lr}\text { Verantwoording } & 31\end{array}$ 


\section{Samenvatting}

Het project Samenwerking Kustverontreiniging na Maritieme Incidenten verkent hoe Rijkswaterstaat gemeenten beter kan assisteren bij het opruimen van de verontreiniging die na maritieme incidenten op de kust aanspoelt. In dit kader is een inventarisatie uitgevoerd van methoden die (kunnen) worden ingezet om aangespoelde microplastics (met name industriële pellets) die door een incident in zee terecht zijn gekomen, langs de kustlijn op te ruimen.

Op hoofdlijnen zijn er drie methoden die gebruikt worden om microplastics te verwijderen te weten opharken, opscheppen of opzuigen, waarna al dan niet een zeef wordt gebruikt om materialen te scheiden.

Opscheppen of opharken zijn geschikte methoden om plastics te ruimen van zachte bodems zonder begroeiing, zoals stranden en eventueel getijdeplaten. Op harde ondergronden, en op vochtig zand is de 'stofzuiger' een effectieve manier om redelijk selectief microplastics te verzamelen. Vooral als de pellets nog bovenop het zand liggen. Als het zand droog is, zal er ook veel zand worden opgezogen en is een combinatie met een zeefsysteem nodig om het zand af te scheiden. Stofzuigen kan ook worden toegepast op begroeid terrein, maar naarmate de begroeiing dichter wordt, neemt de efficiëntie waarmee microplastics worden verzameld af. Voor een effectieve werking van de stofzuigmethode is het verder belangrijk dat wordt vermeden dat grof (plantaardig) materiaal wordt opgezogen omdat dit de opzuigslang snel kan verstoppen. Alle methoden zijn kleinschalig, handmatig in te zetten of grootschalig, gemotoriseerd. Stofzuigen lijkt de meest geschikte methode om aangespoelde microplastics op te ruimen van de verschillende ondergronden. Er zijn enkele firma's die opzuigsystemen, gericht op de verwijdering van microplastics, op de markt aanbieden. Deze zijn al dan niet voorzien van systemen die het afval kunnen scheiden, maar het scheiden van microplastics en plantenresten binnen een groottefractie is op dit moment nog niet mogelijk.

Het is onvermijdelijk dat er bij de opruimacties organismen worden beschadigd of verwijderd. Wanneer dit echter in een beperkt gebied plaatsvindt dan is snel herstel vanuit omliggend terrein mogelijk, mits de structuur van de ondergrond niet door de opruimacties is veranderd. Stofzuigen heeft daardoor de voorkeur boven afgraven en maaien.

Om het gebied dat opgeruimd moet worden tot het minimum te beperken is een snelle respons na een incident belangrijk, omdat het plastic dan geruimd kan worden terwijl het nog geconcentreerd in het vloedmerk ligt. Idealiter wordt een getroffen strand afgesloten voor publiek zodat de plastics niet door betreding of voertuigen dieper in het zand terecht komen. Voor kwelders is snel handelen belangrijk als de plastics zich nog laag op de kwelder bevinden waar de begroeiing minder dicht is. Dicht begroeide kwelders (en slibbige getijdenplaten) zijn moeilijk schoon te maken zonder substantiële impact op het lokale systeem. Idealiter wordt verontreiniging van deze gebieden voorkomen door de plastics vroegtijdig op het water op te vangen, bijvoorbeeld door gebruik te maken van oliekerende schermen. Als er toch microplastics in deze gebieden terecht komen, lijkt 'niets doen' de beste optie, omdat de impact van de aanwezigheid van plastic pellets op het ecosysteem gering lijkt. Zonder gericht onderzoek blijft dit echter een aanname. Mogelijk zijn ecologische effecten van pellets te subtiel om onder veldcondities waar te nemen, maar alleen al vanuit ethisch en esthetisch oogpunt zal verloren afval altijd zoveel mogelijk opgeruimd moeten worden.

Voor het verder ontwikkelen van kennis hoe het best te reageren na een incident met microplastics zou uitwisselen van kennis en ervaring op dit gebied binnen Nederland en eventueel Europa moeten worden bevorderd. Wanneer in dit kader verschillende prototypen van opruimsystemen kunnen worden getest kan een beter beeld van de werkelijke effectiviteit worden verkregen. Door deze samenwerking kan wellicht ook het marktperspectief worden geboden dat commerciële partijen kan aanzetten tot investeren in verbetering van de opruimmethoden. 


\section{Summary}

The project Samenwerking Kustverontreiniging na Maritieme Incidenten (Cooperation Coastal Pollution after Maritime Incidents) explores how Rijkswaterstaat can better assist municipalities in cleaning up pollution that washes up on the coast after maritime incidents. In this context, an inventory has been made of methods that can be used to clean up the coastline from microplastics (particularly industrial pellets) that have ended up in the sea as a result of an incident.

Broadly speaking, there are three methods used to remove microplastics, namely raking, shovelling or vacuuming, after which a sieve may or may not be used to separate materials.

Shovelling or raking are suitable methods for removing plastics from soft sediments without vegetation, such as beaches and possibly tidal flats. On hard substrates, and on moist sand, the 'hoover' is an effective way to collect microplastics reasonably selectively, especially as long as the pellets are still on top of the sand. If the sand is dry, a combination with a sieving system is needed to separate the microplastics from the sand that is also collected. Vacuum cleaning can also be applied to overgrown areas, but as the overgrowth becomes denser, the efficiency with which microplastics are collected decreases. For the vacuum method to work effectively, it is also important to avoid vacuuming coarse (plant) material, as this can quickly clog the vacuum hose. All methods can be used on a small scale, manually, or on a large scale, motorised. Vacuum cleaning seems to be the most suitable method for cleaning up washed-up microplastics from the various substrates. There are a few companies that offer vacuum cleaning systems for the removal of microplastics on the market. These may or may not be equipped with systems that separate the waste, although separating microplastics and plant remains within a size fraction is not possible at present.

It is inevitable that organisms will be damaged or removed during clean-up operations. However, if this takes place in a limited area, quick recovery from the surrounding terrain is possible, provided that the structure of the subsurface has not been changed by the clean-up operations. Therefore, vacuuming is preferable to excavating and mowing.

To minimise the area that needs to be cleaned up, a fast response after an incident is important, as the plastic can then be cleared while still concentrated in the flood mark. Ideally, an affected beach should be closed to the public so that plastics do not end up deeper in the sand through foot traffic or vehicles. For salt marshes, it is important to act quickly if the plastics are still low on the marshes where the vegetation is less dense. Densely vegetated salt marshes (and silty tidal flats) are difficult to clean without substantial impact on the local system. Ideally, contamination of these areas is prevented by collecting the plastics from the water at an early stage, for example by using oil screens. If microplastics do end up in these areas, 'doing nothing' seems to be the best option, as the impact of the presence of plastic pellets on the ecosystem seems small. However, without specific research, this remains an assumption. It is possible that the ecological effects of pellets are too subtle to be observed under field conditions, but from an ethical and aesthetic point of view, lost waste should always be cleaned up as much as possible.

For the further development of knowledge on how best to react after an incident with microplastics, the exchange of knowledge and experience in this field should be promoted within the Netherlands and possibly Europe. If various prototypes of clean-up systems can be tested in this context, a better picture of their actual effectiveness can be obtained. This cooperation may also provide the market perspective that can encourage commercial parties to invest in improving the clean-up methods. 


\section{Inleiding}

\subsection{Aanleiding}

Het gebruik van kunststof is sinds de industrialisering sterk toegenomen en in het jaar 2019 omvatte de wereldwijde productie 368 miljoen ton (PlasticsEurope, 2020). Een deel van dit materiaal komt in zee terecht, en plastics in het milieu worden wereldwijd als een serieus probleem beschouwd (UNEP 2011). Dieren kunnen in macroplastics verstrikt raken of plastic deeltjes inslikken, per ongeluk of per vergissing omdat zij het voor voedsel aanzien (Kühn \& Van Franeker, 2020). Het effect van ingeslikt plastic op natuurlijke populaties is in de veldsituatie moeilijk te bepalen en daarom nog steeds onderwerp van discussie. In laboratoriumstudies worden wel negatieve effecten aangetoond, maar vaak alleen bij hoge plastic concentraties onder niet natuurlijke omstandigheden. Onder meer natuurlijke condities in experimentele ecosystemen werden dergelijke effecten echter niet gereproduceerd en leken vissen de plastic korrels als oneetbaar te herkennen (Foekema et al., 2021). Grote hoeveelheden macroplastics kunnen aanzienlijke oppervlaktes op de zeebodem, koraalriffen of langs de kusten bedekken en zodoende transport van licht en zuurstof beperken (zie bv. de CarvalhoSouza et al., 2018). Daarnaast is er sprake van economische schade. Plastic raakt verstrikt in scheepsschroeven en vervuilde stranden worden minder vaak door toeristen bezocht en moeten geschoond worden. In een rapport van 2010 werd uitgerekend, dat Nederlandse en Belgische kustgemeenten gemiddeld meer dan 10 miljoen Euro per jaar uitgeven aan de schoonmaak van stranden (Mouat et al., 2010). Uiteraard worden hiermee ook natuurlijke materialen die aanspoelen opgeruimd, maar de cijfers geven aan dat chronische vervuiling van stranden een substantiële aanzienlijke economische schade veroorzaakt.

Naast de chronische vervuiling met plastics uit verschillende bronnen, komen ook met regelmaat hoeveelheden plastics via incidenten in zee terecht, bijvoorbeeld doordat containerschepen bij zwaar weer een deel van de lading verliezen, zoals in januari 2019 ten noorden van de Waddenzee gebeurde met de MSC Zoe.

Naar schatting sloegen tussen 2008 en 2019 wereldwijd gemiddeld meer dan 1382 containers per jaar overboord. Maar in jaren met grote containerrampen kan dit aantal oplopen tot meerdere duizenden containers (WSC, 2020). Uit die overboord geraakte containers gaat per jaar naar schatting tussen 300 en 10.500 ton plastic verloren (Galafassi et al., 2019). Dergelijke ongelukken komen wereldwijd voor, maar opruimacties worden vaak lokaal oppakt, zonder dat er veel coöperatie tussen landen plaats vindt of dat kennis van eerdere gebeurtenissen wordt gedeeld. Ook op wetenschappelijke basis is er weinig gepubliceerd over dit soort ongelukken en de nasleep ervan.

\subsection{Samenwerking Kustverontreiniging Maritieme Incidenten}

Het project Samenwerking Kustverontreiniging na Maritieme Incidenten verkent hoe Rijkswaterstaat gemeenten beter kan assisteren bij het opruimen van de verontreiniging die na maritieme incidenten op de kust aanspoelt. Dit geeft invulling aan de toezegging van de Minister in een Kamerbrief ${ }^{1}$ om naar aanleiding van het incident met de MSC Zoe te laten verkennen hoe in de toekomst de milieuimpact door plastic verontreiniging na maritieme incidenten in samenspraak met gemeenten kan worden beperkt. In het algemeen zijn macroverontreinigingen effectiever en betrouwbaarder op te ruimen dan microverontreinigingen. Daarom onderzoekt de overheid de handelingsruimte voor het opruimen van microverontreinigingen na maritieme incidenten, waarbij plastic microverontreiniging is gedefinieerd als vaste plastic bolletjes/pellets van maximaal $5 \mathrm{~mm}$ grootte (microplastics), die als gevolg van een maritiem incident op de kust terecht is gekomen.

\footnotetext{
${ }^{1}$ Kamerstuk 27625, nr. 523 | https:// officielebekendmakingen.nl/kst-27625-523.html
} 
Er zijn twijfels over de uitvoerbaarheid van het ecologisch verantwoord en kosteneffectief opruimen van microplastics in de kustzone. Het materiaal verspreidt zich snel en is moeilijk te scheiden van organisch materiaal en levende organismen. Meer duidelijkheid is nodig over de praktische inzetbaarheid en mogelijke ecologische effecten van bestaande opruimtechnieken. Daarom is door Wageningen Marine Research (WMR) in opdracht van RWS een inventarisatie uitgevoerd van bestaande en innovatieve methodieken/technologieën die kunnen worden ingezet om microplastics in de kustzone op te ruimen. Dit rapport beschrijft het resultaat van deze inventarisatie.

\subsection{Kennisvraag en doelstelling}

Het doel van het in dit rapport beschreven onderzoek was een inventarisatie te maken van bestaande en innovatieve methodieken/technologieën die kunnen worden ingezet om microplastics in de kustzone op te ruimen.

Deze dienden in beeld te worden gebracht en zoveel mogelijk te worden beoordeeld aan de hand van de volgende criteria:

- Ecologische effecten en risico's (ook i.r.t. natuurgebieden)

- Kosten (incl. kosten voor "beheer'; opslag, onderhoud (keuren), testen, innoveren).

- Effectiviteit (voor welk type verontreiniging is de methode effectief, welk deel van de verontreiniging kan worden opgeruimd, opruimen van stranden met een lage dichtheid van microverontreiniging versus opruimen van zichtbare hotspots)

- Technische en praktische uitvoerbaarheid (o.a. op welke soort ondergrond is de technologie toepasbaar, hoe snel is de techniek inzetbaar langs de kust, hoe lang duurt het opruimen)

- Status ontwikkeling (o.a. ideeënfase, pilotfase)

Daarnaast is getracht om ook zoveel mogelijk onderstaande aanvullende vragen te beantwoorden:

- Wat zijn de meest relevante drempels en kennisleemtes voor het opruimen van microplastics op stranden (veroorzaakt door maritieme incidenten)?

- Wat is nog nodig voor het ontwikkelen van geschikte technologie?

- (Hoe) kan kennis over verspreidingsroutes van microplastics in zee naar de kust worden gebruikt om de efficiëntie van het opruimen te verhogen?

- Zijn er technieken om de verspreiding van microplastics op de kust te verminderen/ voorkomen zodat efficiënter kan worden opgeruimd?

- Is het kansrijk om drijvende microplastics op te ruimen (voordat dit aanspoelt)? Zo ja, hoe kan dit worden vormgegeven aanvullend aan het opruimen op de kust?

- Hoe verhoudt het opruimen van microplastics zich tot gelijktijdig opruimen van groter zwerfafval (bv kansen/ risico's belichten)?

\subsection{Werkwijze}

Een deel van de inventarisatie is uitgevoerd aan de hand van informatie uit internationale wetenschappelijke en populaire literatuur en van verschillende websites. Daarnaast zijn telefonische interviews gehouden met beleidsmakers, bedrijven, vrijwilligers en NGO's die op een of andere wijze betrokken zijn (geweest) bij het opruimen van micropastics langs de kustlijn in Nederland of daarbuiten. Er is voor gekozen om geïnterviewden niet persoonlijk te citeren maar de resultaten van deze interviews samen te vatten. De namen van de geïnterviewden zijn opgenomen in het dankwoord. 


\section{Achtergrond informatie}

\subsection{Container incidenten met plastics}

Er bestaat geen wereldwijde lijst van containerverliezen op zee. Ook de inhoud van verloren containers blijft vaak onduidelijk. Reders zijn, ook na ongelukken, niet verplicht om de inhoud van een container openbaar te maken.

In 1990 verloor de 'Hansa Carrier' in de noordelijke Stille Oceaan 21 containers met 61,000 Nike sportschoenen. Die schoenen spoelden jarenlang aan langs de kusten van de Verenigde Staten en Canada. Dit container incident is de eerste, waarbij plastic gebruikt werd om oceaanstromingen te volgen en beter te begrijpen (Ebbesmeyer et al., 1992). Later, in 1992 kwamen er in de Stille Oceaan bijna 30,000 stukken plastic speelgoed bij (plastic eenden, schildpadden, bevers en kikkers) die uit overboord gevallen containers in zee terecht kwamen. Dit speelgoed legde deels indrukwekkende reizen af. Het werd nog jaren later in de VS en Japan gevonden, maar kwam zelfs ook in Schotland en aan de Amerikaanse oostkust terecht (Ebbesmeyer \& Scigliano, 2007).

In 1997 verloor de 'Tokio Express' in slecht weer voor de kust van Cornwall 62 containers, die onder meer circa 5 miljoen Lego stukjes bevatte, vaak in ongebruikelijke, goed herkenbare vormen, bv. Lego draken (Figuur 1), piraten, inktvissen, (duik)flippers, zuurstofflesjes en bloemen. Jaren later brak een container open en verspreidde het Lego zich over de Engelse kusten, maar ook in Nederland werd Lego uit die container gevonden.

In Januari 2014 gingen midden op de Noord-Atlantische oceaan containers overboord, vermoedelijk afkomstig van het schip 'Suez Canal Bridge' maar dat is nooit bevestigd. Een opvallend voorwerp dat in grote aantallen aanspoelde waren HP drukker patronen. Deze werden gevonden in Florida maar ook in Troms $\varnothing$, Noord-Noorwegen. De meeste spoelden echter aan op de Ierse en Engelse kusten en langs de Europese vasteland kust. De verspreiding van dit goed traceerbare materiaal werd gebruikt voor wetenschappelijk onderzoek. Stromingspatronen werden onderzocht maar ook de geleidelijke afbraak van kunststof en daarmee gerelateerde giftige stoffen en metalen kon onderzocht worden (Turner et al., 2021). Bovenstaande gevallen illustreren dat op zee verloren (micro)plastics een lange weg kunnen afleggen voordat zij ergens stranden.

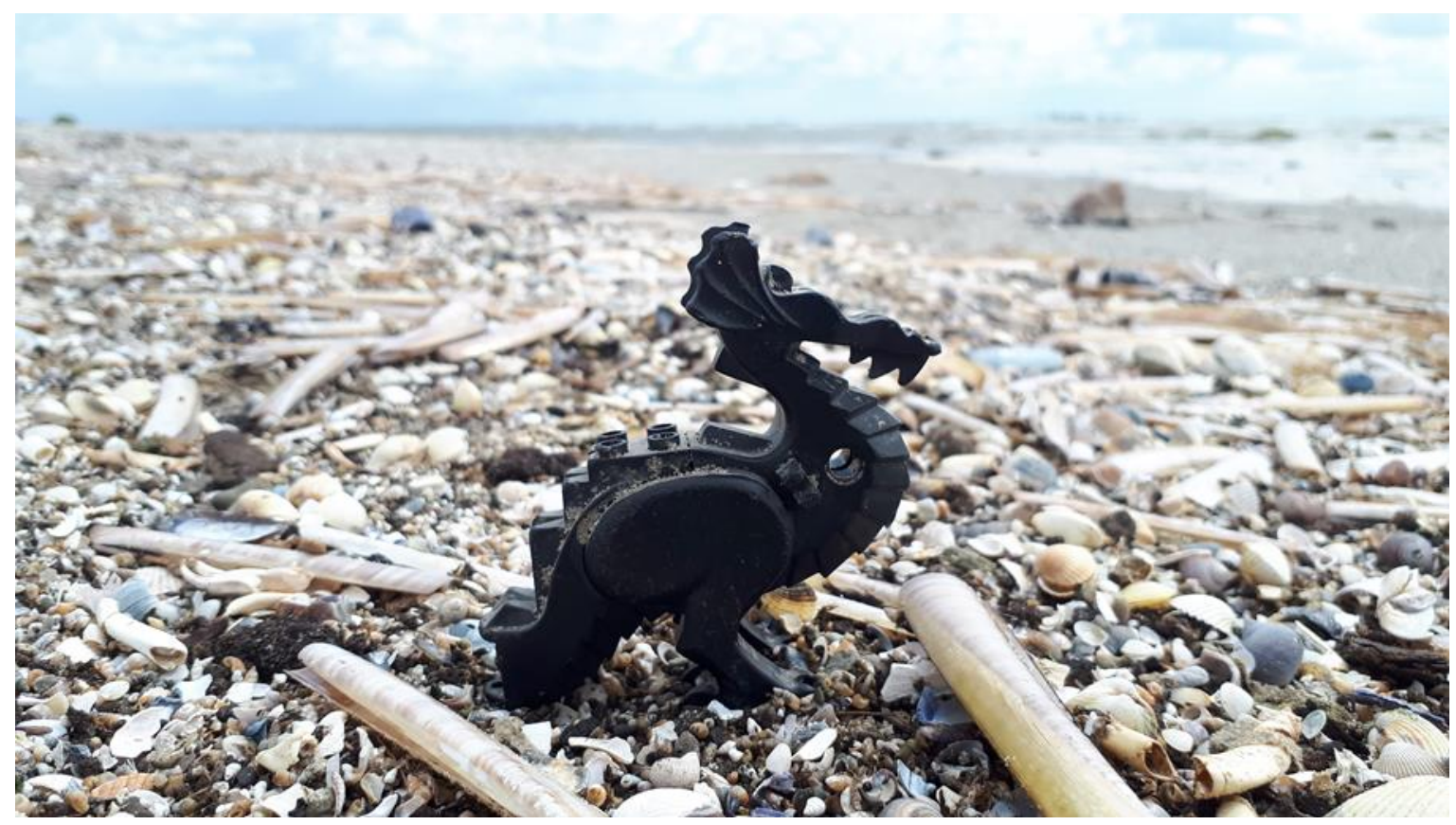

Figuur 1 Een Lego draak, gevonden op het Nederlandse eiland Griend in april 2020. De Tokio Express verloor in 1997 onder andere 33.941 van dit soort draken voor de kust van Wales. Foto: Job ten Horn. 
Wanneer het, zoals in de hierboven beschreven voorbeelden, specifieke herkenbare producten betreft die gerelateerd kunnen worden aan een incident dan is het mogelijk een verantwoordelijke partij aan te wijzen. Dit is een stuk moeilijker bij het verlies van microplastics in de vorm van 'anonieme' halffabricaten (pellets) die vaak wereldwijd worden geproduceerd en gebruikt.

In de Noordzee zijn twee recente gevallen bekend waarbij, veel pellets overboord zijn gegaan. In de eerste dagen van het jaar 2019 verloor de 'MSC Zoe' in een storm 342 containers ten noorden van de oostelijke Nederlandse Waddeneilanden. In de daaropvolgende maanden werden 299 containers of delen daarvan geborgen (Rijkswaterstaat, 2021). Naar schatting ging bij dit ongeluk, naast vele grote plastic voorwerpen, $600 \mathrm{~kg}$ aan polyethyleen pellets verloren, deels los maar deels ook nog in intacte zakken van 25 kilogram die kort na het incident bijvoorbeeld op de kwelder van Groningen werden aangetroffen (Figuur 2). De pellets spoelden in grote getalen aan op de stranden van Schiermonnikoog (Philippart et al., 2019). Op juridisch niveau kon niet worden vastgesteld dat deze van MSC Zoe afkomstig waren, omdat informatie over de exacte inhoud van de verloren containers wellicht niet bekend was, maar in elk geval niet werd gedeeld.

Ruim een jaar later, in februari 2020, ging op de centrale Noordzee 13 ton plastic pellets overboord van het containerschip 'MV Trans Carrier'. De polypropyleen pellets spoelden in grote hoeveelheden aan langs de Deense, Noorse en Zweedse kusten. In Noorwegen kon, met veel inspanning 4.4 ton van de pellets worden opgeruimd (Dolva, 2020).

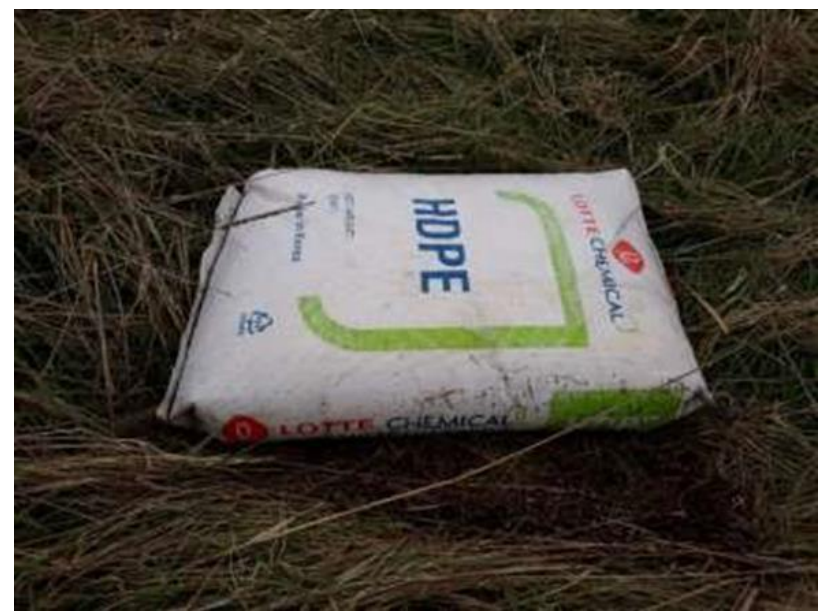

Figuur 2 Een zak HPDE pellets die na het incident met MSC Zoe werd aangetroffen op een Groninger kwelder (Foto: Cor Sonneveld)

\subsection{Effecten van plastic pellets op soorten en ecosystemen}

Plastic pellets in magen van zeedieren zijn al in de jaren 60 van de vorige eeuw waargenomen en behoren daarmee bij de vroegste meldingen van plastics die door dieren ingeslikt waren. De eerste waarneming komt uit de periode 1958 tot 1978, waarin pellets in Nieuw Zeelandse zeevogels aangetroffen werden (Harper \& Fowler, 1987). In de jaren 70 werden ze ook gevonden in de magen van zeevogels uit de noordelijke Stille Oceaan (Day, 1980; Ogi, 1990). In 1971 werden pellets ook in vismagen ontdekt, eerst langs de Atlantische kust (Carpenter, 1972) en in 1972 ook in Noordzeevis (Kartar 1976). Ondertussen zijn er meer dan 100 mariene soorten met pellets in hun maag gerapporteerd, niet alleen vissen en zeevogels, maar ook verschillende schelpdieren, zeeschildpadden en zeezoogdieren (S. Kühn, ongepubliceerde data). In Nederland zijn vooral noordse stormvogels (Fulmarus glacialis) bekend als plastic pellet eters. Vanaf circa 1980 is de hoeveelheid pellets in de magen van deze vogels wel significant afgenomen. Tegenwoordig hebben stormvogels gemiddeld 1.6 plastic pellets per maag (meet periode 2016-2020; Kühn et al., 2021). In Nederland zijn plastic pellets verder ook aangetroffen in andere zeevogels, zoals meeuwen en duikers (Van Franeker, 1983; Foekema et al., 2020) en bruinvissen (Van Franeker et al., 2018).

De pellets die tijdens het MSC Zoe incident verloren gingen, werden, niet teruggevonden in de ingewanden aan de verschillende onderzochte diersoorten, ondanks grondig onderzoek. Alleen in een 
braakbal van een kleine mantelmeeuw (Larus fuscus) op Schiermonnikoog werden pellets gevonden die erg op de Zoe pellets leken (Foekema et al., 2021).

In twee van de 50 eidereenden (Somateria mollissima), die kort na het incident met MV Trans Carrier dood aan Noorse stranden aanspoelden, werden pellets gevonden die op de verloren pellets leken (Hanssen et al., 2020). Er werden geen pellets teruggevonden in 633 onderzochte vissen, die tijdens hetzelfde incident werden onderzocht (Boitsov et al., 2020).

Over effecten van ingeslikte pellets is weinig bekend. In 1988 werden kippen onder experimentele omstandigheden met poly ethyleen (PE) pellets gevoerd. Kippen met pellets in hun maag aten minder en groeiden langzamer. Volgens de onderzoekers had dit te maken met het door plastic beperkte volume in de magen van de dieren, waardoor er minder hongergevoel en minder ruimte voor voedsel was (Ryan 1988).

Effecten op in het wild levende dieren zijn naar ons weten nog nooit met zekerheid vastgesteld. Onder semi-veld condities is met kleinere plastic korrels (diameter $0.7 \mathrm{~mm}$ zoals verloren door MSC Zoe) een zeer geringe afname van de conditie van juveniele tong vastgesteld, wat kan duiden op een iets vertraagde darmpassage in aanwezigheid van het plastic. Zelfs bij de hoogste dosering van ca. 30 korrels per $\mathrm{cm}^{2}$ bleef dit verschil zo klein dat het in een veldsituatie nooit waargenomen zou kunnen worden. Het geringe aantal vissen met plastic in de het maagdarmkanaal en het lage aantal korrels per visje duidde erop dat de vissen de korrels als oneetbaar herkenden, en dat per ongeluk ingeslikte korrels niet in het maagdarmkanaal accumuleerden (Foekema et al., 2019).

Tijdens de productie van plastic pellets kunnen in verschillende stappen chemicaliën worden toegevoegd, die noodzakelijk zijn om het plastic de gewenste kleur, flexibiliteit en andere eigenschappen te geven. Deze stoffen worden ook additieven genoemd. Zij zijn goed in de plastic matrix 'ingebakken', maar kunnen onder sommige omstandigheden ook uit het materiaal lekken. Niet in alle pellets zijn dergelijke additieven aanwezig. In de na het incident met de MSC Zoe aangetroffen pellets konden dergelijke stoffen niet worden aangetoond (Foekema et al., 2021).

De pellets kunnen ook vervuilende stoffen uit zeewater absorberen, waaronder de zogenoemde 'Persistent Organic Pollutants' (POP's), zoals bijvoorbeeld PCB's (polychloorbifenylen) en gebromeerde vlamvertragers. De hoeveelheid van deze stoffen in pellets kan daardoor de concentratie van dezelfde stoffen in het omliggende zeewater overstijgen (Mato et al., 2001; Endo et al., 2005), zoals ook het geval is met de gehalten van deze bioaccumulerende stoffen in planten en dieren die in hetzelfde water aanwezig zijn.

Beide stoftypes, de additieven en POPs, kunnen via plastics door zeedieren worden opgenomen, maar de mate waarmee dit bijdraagt aan de totale blootstelling is onduidelijk. Vooral voor POP's is het onwaarschijnlijk dat ingeslikte plastics in een natuurlijke situatie een belangrijke rol spelen als blootstellingsroute, omdat deze stoffen ook in belangrijke mate in de natuurlijke prooien aanwezig zijn en bij passage van het maagdarmkanaal daarvan makkelijker loskomen dan van plastics (Koelmans et al., 2013a; 2013b). Recent onderzoek toonde aan dat kuikens van wilde zeevogels die met plastic pellets werden gevoerd waar additieven (vlamvertragers en UV- stabilisatoren) aan waren toegevoegd, duidelijk verhoogde waardes van deze stoffen in hun lever en vet hadden (Tanaka et al., 2020). Dit resultaat bevestigt de eerdere aanname van dezelfde onderzoekers dat in afgelegen schone gebieden, microplastics een meetbare bron kunnen zijn van additieven voor zeevogels (Tanaka et al., 2018).

Ook over de effecten van verloren pellets op het ecosysteem is weinig bekend. Als extreme grote hoeveelheden plastic de (zee)bodem op grote vlaktes bedekken, kunnen zuurstof- en lichttransport verstoord worden (de Carvalho-Souza et al., 2018). De hoeveelheid biomassa onder het plastic kan dan afnemen (Green et al., 2015). Voor zover ons bekend zijn er nog geen sterfgevallen of ecologische effecten gerapporteerd die zonder twijfel gelinkt konden worden aan verloren plastic pellets. 


\section{Inventarisatie bestaande opruimtechnieken}

\subsection{Handmatig harken}

Oorspronkelijk is er een hark ontworpen om grotere microplastics op stranden beter te kunnen monitoren. Bij het ontwerp door Haseler et al. (2018, 2019, 2020) wordt een grote halfrond zeef aan een stok bevestigd die dan door het zand heen getrokken kan worden (Figuur 3). Er kunnen zeven van verschillende maten ingebouwd worden. De standard zeef is een halve meter breed, heeft een maaswijdte van $2 \mathrm{~mm}$ en zeeft, volgens de auteurs, de bovenste $3-5 \mathrm{~cm}$ van het zand schoon. Met deze afmetingen kunnen pellets betrouwbaar verzameld worden. Die methode is geschikt voor droog zand, op en naast de vloedlijn. Op moment dat het zeef vol is, moeten natuurlijke voorwerpen en kunststof of afval handmatig gesorteerd worden. Tijdens een experiment, waarbij kleine plasticstukjes op het proefvlak verdeeld werden, kon meer dan $50 \%$ van de plastics terug worden gevonden (Haseler et al., 2020). Dit werkte 30 keer beter dan het vinden van plastic alleen op oog. Om een stuk strand van $100 \mathrm{~m}^{2}$ schoon te maken, hadden 2 mensen ongeveer 5 uur nodig en waren daarmee efficiënter dan mensen die met de hand zand in een draagbaar zeef gooiden en op die manier een vergelijkbaar stuk strand schoon maakten (Haseler et al., 2020). De kosten voor het voorwerp zelf zijn laag, de auteurs schatten tussen de 150 en 250 Euro. Men hoeft niet veel ervaring te hebben om met de hark om te gaan en plastics van natuurlijke voorwerpen te scheiden. Voor nat zand is de methode minder geschikt en op stenen ondergrond werkt de hark helemaal niet (Haseler et al., 2019).
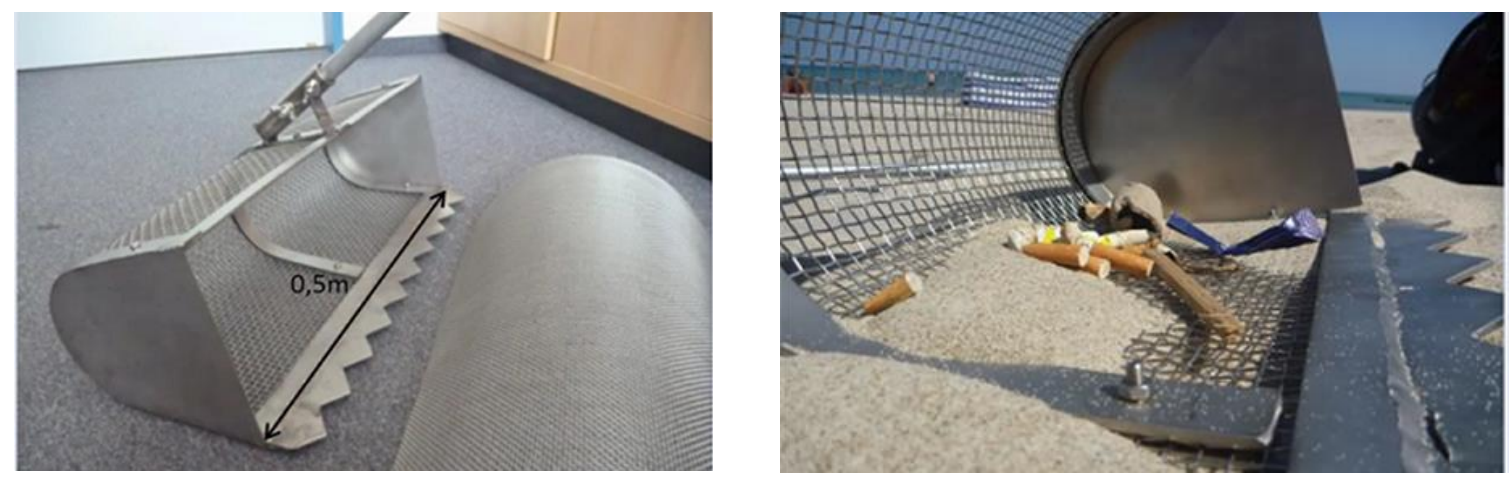

Figuur 3 De hark, ontworpen door Haseler en collega's. De maaswijdte op de foto's is 5 mm, maar kan makkelijk veranderd worden om ook pellets betrouwbaar de verzamelen.

\subsection{Handmatig zeven}

Wereldwijd zetten vrijwilligers zich in om microplastics uit het milieu te verwijderen. Op stranden gebeurt dit veelal door de toplaag van het zand op te scheppen en daarna handmatig te zeven. Vrijwilligers van de 'Bende van Strand' verbouwden hiervoor een bolderkar waarop twee zeven, een grove en een fijne, boven elkaar zijn geplaatst (Figuur 4). Deze zeven worden door een elektromotor in trilling gebracht waardoor het materiaal dat hierop geschept wordt zich verdeeld in drie fracties. Op de bovenste zeef blijft het grove materiaal achter, dit bestaat onder andere uit macroplastics en plantaardig materiaal. Op de tweede zeef verzamelt zich het fijnere materiaal waaronder plastic pellets. De kleinste fractie, die voornamelijk uit zand bestaat, zakt door deze zeef en wordt niet verzameld. Als proef is dit zeefsysteem ook gebruikt in combinatie met een zuigslang zodat er niet meer handmatig geschept hoefde te worden. Hierbij werden volgens de bouwers goede resultaten behaald. Zij zien dan ook mogelijkheden om het systeem op te schalen. Scheiding van het op de zeven verzamelde materiaal in afval (plastics) en natuurlijk materiaal gebeurt handmatig. 

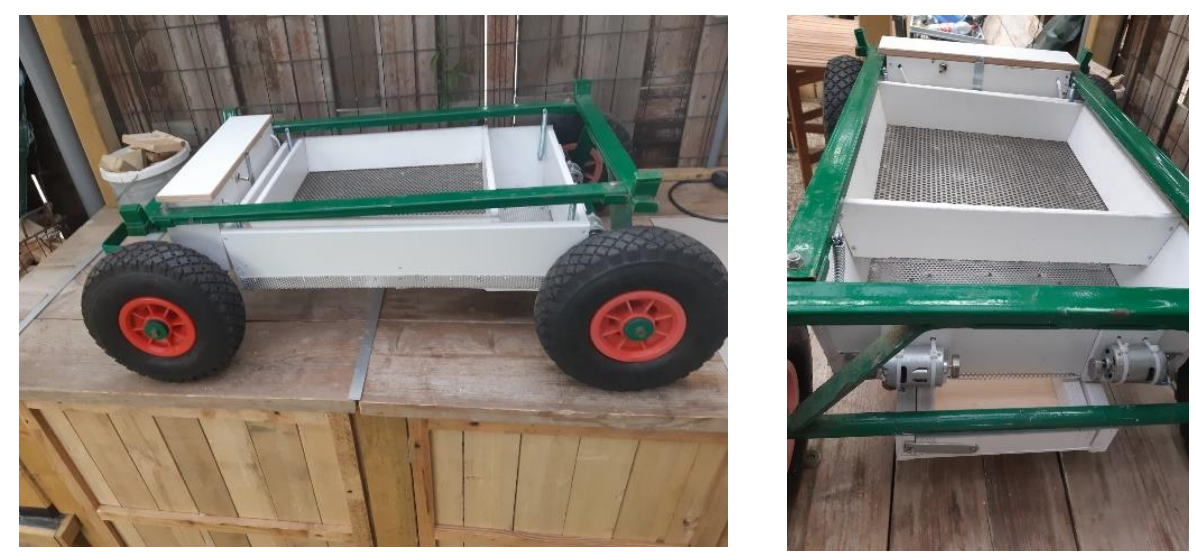

Figuur 4 De zeefbolderkar van de Bende van Strand (https://www.debendevanhetstrand.nl/)

De uit de UK afkomstige groep Nurdle.org brengt hiervoor een trommelzeef op de markt. Dit is de 'Microplastic trommel' die handmatig bediend kan worden en waarmee zand met minder inspanning kan worden gezeefd (Figuur 5). De groep zelf zet deze trommel vooral in om awareness te creëren bij het publiek.

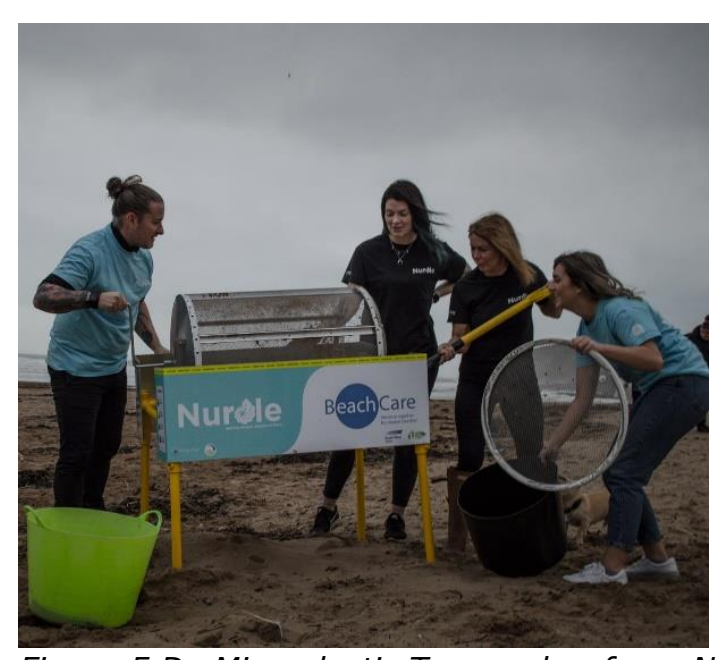

Figuur 5 De Microplastic Trommelzeef van Nurdle (https://nurdle.org.uk/microplastic-trommel)

\subsection{Handmatig stofzuigen}

Handmatige stofzuigers kunnen worden ingezet op verschillende terreinen. Anders dan gemotoriseerde voertuigen met stofzuigers, zijn de handmatige stofzuigers flexibel inzetbaar en kunnen ook op terrein gebuikt worden, waar grote machines veel schade kunnen veroorzaken. Bij het container incident van de 'MV Trans Carrier' werden dergelijke stofzuigers (stofzuigers en bladzuigers) succesvol ingezet (Dolva et al., 2020). De auteurs geven een aantal conclusies en aanbevelingen. Het rugzakmodel is het meest praktische model, waarbij de stofzuiger met een opvangbak op de rug wordt gedragen. Die opvangbak kan worden verbeterd door een zeef aan de onderkant aan te brengen waardoor fijn materiaal zoals zand meteen achter blijft. Er zijn twee types aandrijving, of met brandstof (die gaan langer mee) of met accu's die een wat kortere looptijd hebben maar daarvoor 
duurzamer zijn en minder lawaai veroorzaken. Bij apparaten die een accu nodig hebben is het noodzakelijk om voldoende reserve accu's beschikbaar te hebben. In Noorwegen konden met handmatige stofzuigers vooral plekken tussen de stenen, waar geen grote machines bij kunnen komen, goed worden opgeschoond. Stranden met droge, fijne zand werden minder geschikt bevonden, omdat de opvangbakken toen snel vol raakten.

Over de efficiëntie van handmatige stofzuigers is weinig bekend, maar Dolva et al. (2020) geven de aanbeveling dat het efficiënter is om twee mensen per stofzuiger in te zetten. Terwijl een persoon zuigt, kan de andere zo nodig de inhoud van de opvangbak sorteren of accu's vervangen.

\subsection{Gemotoriseerd stofzuigen}

Voor het professioneel opruimen van microplastics langs kustlijnen worden veelal gemotoriseerde voertuigen ingezet die zijn voorzien van 'stofzuigers'. Hieronder worden enkele beschikbare gemotoriseerde stofzuigsystemen beschreven.

De firma BDS heeft in het voorjaar van 2019 in eerste instantie een zuigklepelmaaier ingezet om aangespoelde plastic pellets uit de duinenrand van Schiermonnikoog te verzamelen. Hierbij werd de vegetatie afgesneden en via een vacuümsysteem in een bak verzameld. Naar schatting werd hierbij $80 \%$ van de pellets verwijderd, maar het leverde ook erg veel plantaardig materiaal op, dat lastig te scheiden was van plastics. Zand werd wel gescheiden op basis van drijfvermogen. Later is de klepelmaaier verwijderd en werd alleen het vacuüm opzuigsysteem gebruikt om materiaal op te zuigen, zonder te maaien (Figuur 6). Volgens waarnemers was het zuigsysteem op ongestoorde delen behoorlijk efficiënt, maar waren de pellets een stuk moeilijker op te zuigen wanneer ze door betreding of voertuigen dieper in het zand terecht waren gekomen. Het opruimen langs de vloedlijn werd beperkt door de wieldruk van het voertuig zodat alleen bij heel laagwater geruimd kon worden. De opruimactie op Schiermonnikoog heeft ca. 2 maanden geduurd en werd beëindigd vanwege de start van het broedseizoen.

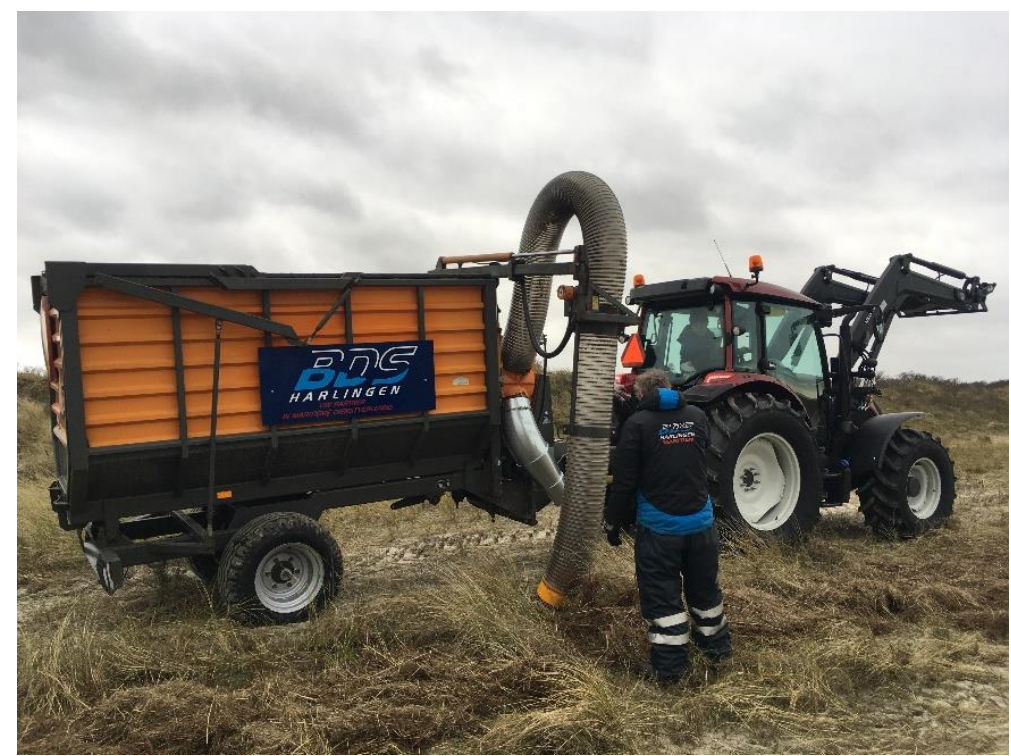

Figuur 6 Firma BDS aan het werk op Schiermonnikoog (Foto Natuurmonumenten)

Voor opruimacties in de haven van Rotterdam gebruikt firma HEBO Maritiem Service een vacuümsysteem dat op een schip geplaatst is om microplastics van dijktaluds te stofzuigen (Figuur 7). Volgens inschatting van HEBO werd in een periode van 3 dagen hiermee $200-400 \mathrm{~m}^{2}$ oppervlak schoongemaakt. Om verstopping van de zuigmond te voorkomen wordt grof materiaal vooraf verwijderd. Het opgezogen materiaal wordt nu nog niet gescheiden. Er zijn wel ideeën hoe dit kan worden aangepakt maar door gering marktperspectief is hier (nog) niet in geïnvesteerd. 


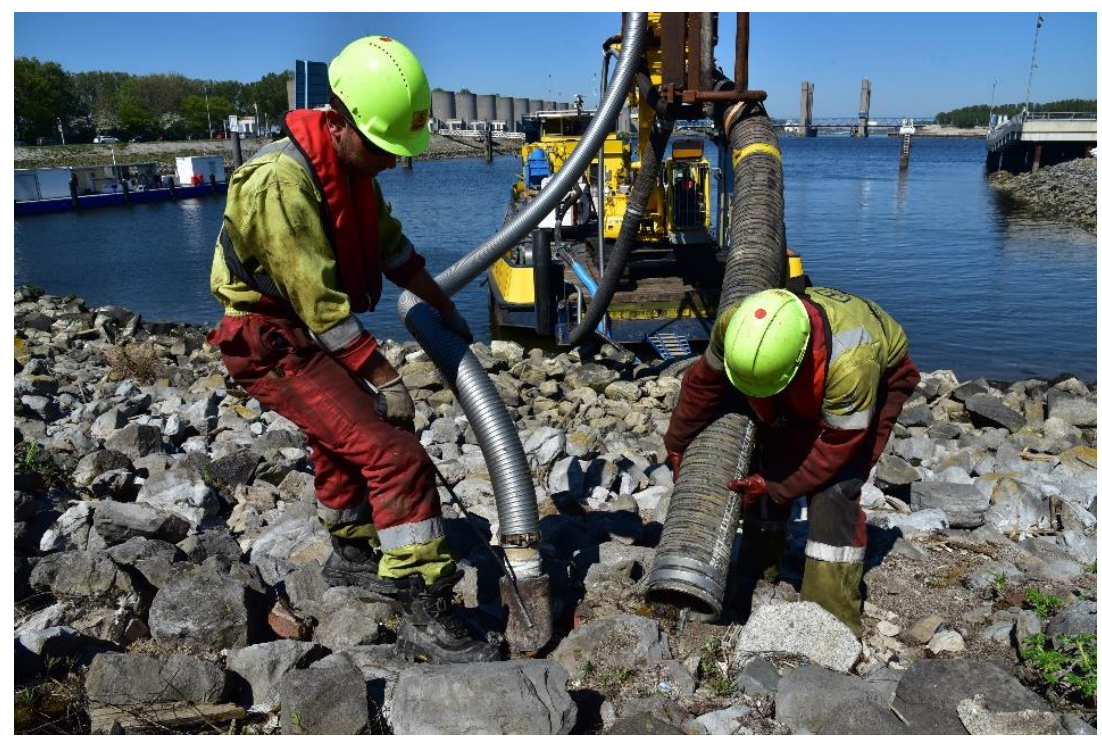

Figuur 7 HEBO Maritiemservice BV verwijdert microplastics in haven Rotterdam met behulp van een stofzuigersysteem op een boot (Foto: HEBO Maritienservice BV; https://www.hebomaritiemservice. $\mathrm{nl} /$ ).

$\mathrm{Na}$ het winnen van een prijsvraag uitgeschreven door de haven van Antwerpen heeft firma Envisan (onderdeel van de Jan de Nul groep) het prototype ontwikkeld van de Nul-O-Plastic, een op rupsbanden uitgevoerd voertuig (wieldruk $200 \mathrm{~g} / \mathrm{cm}^{2}$ ) voorzien van een zuigslang en een opvangbak (Figuur 8). Het systeem is met succes toegepast op harde oevers (dijktaluds) en op schorren met niet te veel begroeiing. Bij ruigere begroeiing nam de effectiviteit af, net als bij vochtig weer, wanneer de pellets aan de ondergrond plakken. Afhankelijk van de ondergrond kon een oppervlakte tussen 0.2 en $1 \mathrm{~m}^{2}$ per minuut worden gereinigd. Het opgezogen materiaal wordt op dit moment in zijn geheel verbrand omdat scheiden van plastics en organisch materiaal lastig is. De Nul-O-Plastic is niet getest op het strand omdat daarbij naar verwachting te veel zand wordt meegezogen. De operationele kosten van het reinigen met deze machine bedragen ca. 300 euro/uur.

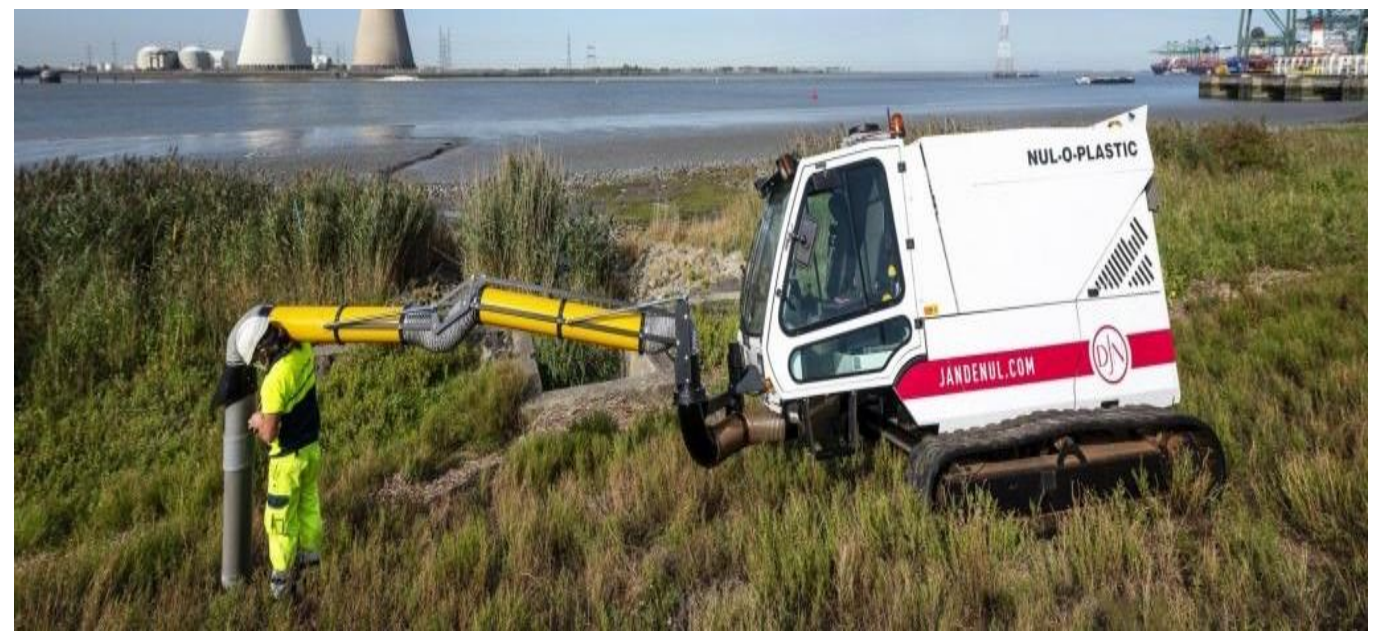

Figuur 8 De Nul-O-Plastic van Firma Envisan

Buiten Nederland zijn ook meerdere opruimsystemen op basis van het stofzuigerprincipe ontwikkeld, waarvan er enkele commercieel beschikbaar zijn of komen. De 'Microplastic-machine' van Nurdle (UK; https://nurdle.org.uk/microplastic-machine/) is gebouwd op een kar die achter een voertuig (Quad) kan worden gekoppeld (Figuur 9). Het prototype systeem wordt op dit moment getest op effectiviteit op ecologische impact in samenwerking met de University of Southampton en zal naar verwachting rond april 2022 commercieel beschikbaar zijn, tegen een verwachtte kostprijs van rond 15.000 euro. De Microplastic-machine kan naar keuze worden uitgerust met een brede zuigmond voor gebruik op vlakke stranden of met een 7 meter lange smalle zuigslang wanneer het schoon te maken terrein 
moeilijk bereikbaar is of veel begroeiing en/of hoogteverschillen kent. Het opgezogen materiaal wordt gescheiden over 3 schudzeven, waarvan de maaswijdte aangepast kan worden aan de situatie. Elke zeeffractie wordt in een aparte 'afvalzak' verzameld, zodat fracties die weinig/geen plastics bevatten in het onderzoeksgebied kunnen worden teruggebracht. Inmiddels wordt door Nurdle gewerkt aan een methode om plastics van plantaardig materiaal van hetzelfde formaat te scheiden, maar dit systeem zal in april 2022 nog niet commercieel beschikbaar zijn.

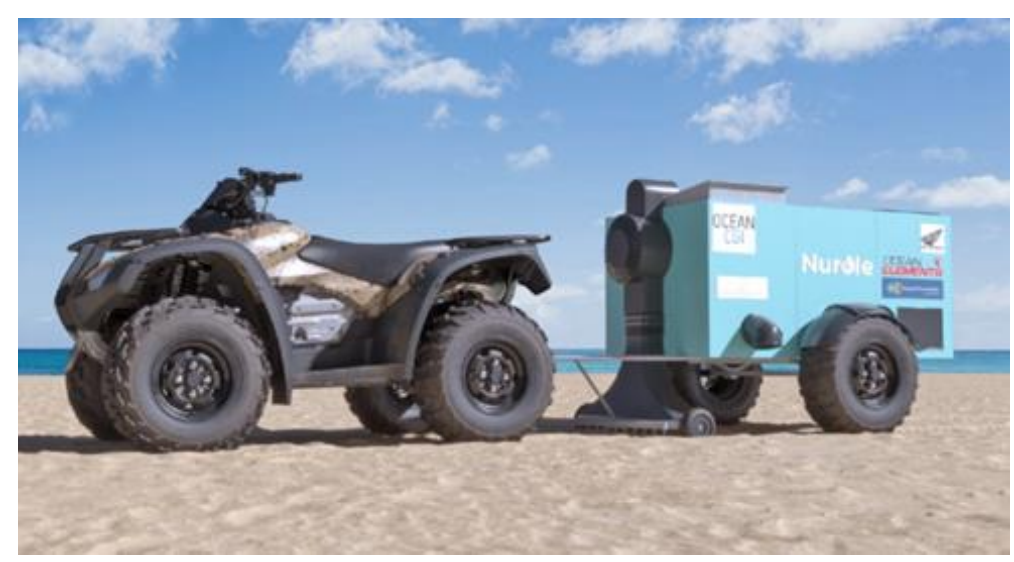

Figuur 9 Microplastic machine van Nurdle.org, hier uitgerust met de 'stofzuigermond' om plastics van het vlakke zand op te zuigen (https://nurdle.org.uk/microplastic-machine/)

In Canada ontwikkelde het bedrijf Hoola One (https://hoolaone.com/home/) een gemotoriseerd stofzuigersysteem de HO1, dat gebruik maakt van water om materialen te scheiden op basis van verschil in drijfvermogen. Voor het gebruik van de $\mathrm{HO} 1$ is dan ook continue wateraanvoer nodig. De waterscheidingsmethode is effectief wanneer gewerkt wordt met plakkerig sediment en om zwaarder materiaal zoals schelpen, zand en stenen van plastic te scheiden, maar (plantaardig) materiaal met hetzelfde drijfvermogen als plastics kan hiermee niet worden gescheiden. Het bedrijf geeft wel aan te werken aan een innovatieve technologie, met de naam FiltrUs, waarvan ze verwachten dat volledige scheiding van organisch materiaal en plastic mogelijk wordt. Deze technologie zal niet voor 2024 gereed zijn. Met de HO1 zou een oppervlakte van circa $60 \mathrm{~m}^{2}$ per uur opgeruimd kunnen worden. Het zal naar verwachting vanaf 2023 op de markt komen tegen en geschatte prijs rond US\$100.000. Hetzelfde bedrijf heeft ook recentelijk de $\mathrm{HO} 2$ ontwikkeld waarin het materiaal met behulp van zeven wordt gescheiden. Hiervoor is dus geen continue wateraanvoer nodig. Volgens opgave zou de $\mathrm{HO} 2$ op een zandstrand een oppervlakte van circa $200 \mathrm{~m}^{2} / \mathrm{uur}$ kunnen opruimen. Net als alle zeefsystemen werkt deze het beste met droog, los zand. De HO2 is vanaf 2022 commercieel verkrijgbaar tegen een geschatte prijs van rond US\$ 45.000 .

\subsection{Klassieke 'Beach cleaners'}

Op veel toeristenstranden worden 'beach cleaners' ingezet om op efficiënte wijze grof aangespoeld materiaal zoals zeewier en zwerfvuil te verwijderen. Deze beach cleaners, werken volgens een hark-, of een zeefmechanisme dat veelal achter een tractor over het strand wordt gereden

(http://www.beachcleaner.com/beach cleaner-methods.html). Het harkmechanisme is alleen geschikt voor het verzamelen van grof materiaal dat door de hark wordt opgenomen, en is dus niet geschikt voor opruimen van microplastics.

De beach cleaners, die zijn uitgerust met een zeefmechanisme, schrapen de toplaag van het zand en 'schudden dit uit' in een zeef. Wanneer de zeefdiameter minder dan $5 \mathrm{~mm}$ bedraagt, moeten met deze methode ook microplastics kunnen worden verzameld. Dergelijke zeefsystemen worden vooral toegepast op kleinere beach cleaners die op (private) stranden van beperkte omvang worden gebruikt. Veelal worden deze cleaners met de hand bestuurd, maar in de USA is een op afstand bestuurbare robot ontwikkeld, de BeBot. De BeBot schept tot $10 \mathrm{~cm}$ diep zand op dat vervolgens wordt gezeefd op 
een schudzeef met een standaard maaswijdte van $1 \mathrm{~cm}^{2}$. Het systeem lijkt in elk geval effectief in het verzamelen van sigarettenfilters uit droog los zand dat snel door de zeef zakt

(https://www.designboom.com/technology/bebot-robot-tiny-plastic-waste-clean-beaches-4ocen-08-

02-2021/). Maar zoals elk 'droog' zeefsysteem zal de efficiëntie snel afnemen door plakkerig nat zand, zeker als er met kleinere zeefdiameters wordt gewerkt die nodig zijn om microplastics te verzamelen. 


\section{Ecologische impact van opruimacties}

\subsection{Strand}

Kort na een incident zullen op stranden aanspoelende microplastics zich concentreren op de vloedlijn. $\mathrm{Na}$ verloop van tijd, als er meerdere getijden zijn gepasseerd, raken de plastics meer verspreid of zullen zij tijdens een springtij situatie hoger op het strand terecht komen. Dit laatste gebeurde in 2019 op Schiermonnikoog waarbij uiteindelijk veel plastic pellets in de duinenrij terecht kwamen, en daar werden opgeruimd.

Normaal gesproken zal het opruimen van aangespoelde pellets op stranden zich echter voornamelijk richten op het gebied tussen de hoogwaterlijn en laagwaterlijn.

Hoewel een strand op het eerste gezicht weinig leven lijkt te bevatten zijn er toch een aantal kleinere diersoorten die zich in en op het droogvallende zand thuis voelen. Janssen et al. (2005 en 2008) identificeerden een beperkt aantal typische strandsoorten die tot op de hoogwaterlijn van Nederlandse stranden werden aangetroffen. Als belangrijkste soorten noemen zij de gemshorenworm (Scolelepis squamata), en een drietal kreeftachtigen, de strandvlo (Talitrus saltator), de zandvlokreeft (Haustorius arenarius) en het litoraal kniksprietkreeftje (Bathyporeia pilosa).

De hoogste dichtheden en soortenrijkdom van benthische organismen, worden echter iets dieper dan op de gemiddelde waterhoogte aangetroffen. Dit geldt zowel voor zandstranden (Janssen et al., 2005) als meer slibbige getijdengebieden (Beukema, 2002). Op zandstranden bestaat de benthische gemeenschap vooral uit kleine wormen en kreeftachtigen en een enkele (juveniele) schelp. Al deze soorten zijn aangepast aan het periodiek droogvallen van hun leefgebied en zullen zich dan in het sediment begraven. De wormen leven sowieso voornamelijk onder het sediment oppervlak, terwijl de kreeftachtigen vaker aan het oppervlak te vinden zijn waar zij aangespoeld organisch materiaal (zeewier, dode dieren) als voedsel benutten. Zo kunnen volwassen zandvlokreeften tot $15 \mathrm{~cm}$ diep graven (Vader, 1969) terwijl strandvlooien tot $30 \mathrm{~cm}$ diep kunnen worden aangetroffen.

Genoemde wormen en kreeftachtigen vormen voedsel voor vogels die langs de vloedlijn foerageren, zoals drieteenstrandlopers (Calidris alba). Er wordt echter aangenomen dat deze kleine bodemdieren slechts een beperkt deel van het dieet $(<10 \%)$ van de vogels uitmaken (Vanermen et al., 2009), en dat zij zich voornamelijk voeden met eenvoudiger te verkrijgen en groter voedsel in de vorm van aangespoelde dode schelpdieren of kreeftachtigen.

Toeristenstranden worden regelmatig schoongemaakt met behulp van zogenaamde beach cleaners (zie paragraaf 0), waarbij voornamelijk groter afval en aangespoeld zeewier wordt verwijderd. In verschillende studies is een negatief effect van deze schoonmaakacties op het bodemleven aangetoond. Zo zijn negatieve effecten aangetoond op in de bodemlevende dieren die worden 'overreden' door voertuigen (Schlacher et al., 2007). Een waarschijnlijk groter effect is het gevolg van het verwijderen van het aangespoelde natuurlijke materiaal dat het voedsel vormt voor met name kleine kreeftachtigen(Llewellyn \& Shackley, 1996; Zelinski et al., 2019). Naast de vermindering van het voedselaanbod worden met het ruimen ook de dieren van het strand verwijderd die zich in/op het aangespoelde zeewier bevinden. Op stranden die met regelmaat 'geschoond' worden leidt dit tot een substantiële vermindering van het aantal kleine kreeftachtigen, zoals strandvlooien. Vanuit ecologisch perspectief wordt hiervoor aanbevolen om geschoonde en ongeschoonde delen op een strand af te wisselen en het geruimde zeewier naar de ongeschoonde delen te verplaatsen (Zelinski et al., 2019).

Om aangespoelde microplastics van stranden te verwijderen zal gebruik gemaakt worden van opscheppen of stofzuigen, al dan niet gemotoriseerd. Bij opscheppen wordt de bovenste zandlaag verwijderd. In een dynamisch gebied als een zandstrand zal deze oppervlakkige verstoring van het sediment geen nadelige gevolgen voor de omgeving hebben. Afhankelijk van welke graafdiepte bereikt wordt, worden meer of minder in de bodem aanwezige organismen meegenomen. Deze aantallen zullen groter worden naarmate de laagwaterlijn dichter wordt benaderd. Tijdens het zeven van het zand blijft ongetwijfeld een deel van deze organismen op de zeef achter, en raakt een deel 
beschadigd, zodat er in theorie lagere dichtheden bodemdieren zullen ontstaan in de behandelde gebieden. De ecologische impact hiervan zal waarschijnlijk zeer beperkt zijn wanneer het tijdelijke opruimacties betreft en geen regulier 'onderhoud'. De soorten, met name kleine wormen en kreeftachtigen, die worden aangetroffen op zandstranden tussen de hoogwaterlijn en laagwaterlijn, zijn aangepast aan een dynamische omgeving en worden daardoor in staat geacht snel te reageren op dynamische omstandigheden en te herstellen van geringe verstoringen. Als voedselbron zijn zij slechts van beperkt belang voor vogels die langs de vloedlijn foerageren, terwijl (juveniele) vissen hun voedsel ook beneden de laagwaterlijn kunnen vinden waar niet geruimd is omdat drijvende microplastics daar niet zullen stranden. In dit diepere water leven ook veel van de soorten die tussen de laag- en hoogwaterlijn worden aangetroffen, hetgeen het herstel van de levensgemeenschap in het geruimde deel zal versnellen.

Op een aantal stranden broeden vogels die in het kader van Natura2000 van belang zijn zoals de strandplevier, dwergstern en de bontbekplevier. Opruimacties op dergelijke locaties verdienen hierdoor extra aandacht. Juist ook hier is snel handelen belangrijk zodat de plastics rond de vloedlijn worden opgeruimd voordat zij de hoger gelegen delen hebben bereikt waar de vogels nestelen.

\subsection{Getijdenplaten}

Microplastics die worden verloren in de omgeving van de Waddenzee of de Zeeuwse Delta kunnen tijdens laagwater achterblijven op getijdenplaten. Deze platen worden gekenmerkt door een hoge biologische productie, en een relatief hoge biodiversiteit waardoor het belangrijke foerageergebieden zijn voor vogels en vissen tijdens respectievelijk laagwater en hoogwater (zie bijvoorbeeld Christianen et al., 2015).

De veelal slibrijke platen zijn moeilijk begaanbaar en lastig te bereiken met zwaarder materieel waardoor waarschijnlijk in de meeste gevallen alleen handmatige opruimmethoden kunnen worden toegepast. Dit zal gepaard gaan met een intensieve betreding van het gebied. De meeste op deze platen aanwezige organismen kunnen goed omgaan met enige fysieke verstoring van het sedimentoppervlak, maar schelpdieren die diep in het slib worden 'weggetrapt' zullen daar niet van herstellen. Mosselbanken kunnen dan ook beter worden ontzien, omdat herstel van de effecten van betreding meerdere jaren in beslag kan nemen.

Omdat getijdenplaten per definitie onder de hoogwaterlijn liggen zullen daarop afgezette drijvende plastic pellets tijdens hoogwater weer worden afgevoerd. Het is daarom niet waarschijnlijk dat deze plastics hier zullen accumuleren. Het opruimen van microplastics van getijdeplaten lijkt daardoor geen logische eerste keuze na een incident.

\subsection{Kwelder}

Kort na een incident kan verwacht worden dat drijvende microplastics op een kwelder verspreid worden over een gebied tot aan het hoogwater vloedmerk. Het meeste plastics worden echter waarschijnlijk gedeponeerd ter hoogte van het vloedmerk zelf, zoals in eerder onderzoek door Viehman et al. (2011) werd geconstateerd. Na verloop van tijd echter kan het microplastic met meerdere getijden over een breder gebied tussen de laagwaterlijn en hoogwaterlijn over de kwelder worden verspreid, zoals ook op stranden het geval is. Met dezelfde getijdebewegingen bezinkt ook sediment, waaronder op den duur microplastic deeltjes zullen worden begraven (Lloret et al., 2021).

De aanwezigheid van planten bemoeilijkt het opruimen van microplastics die aanspoelen op de kwelders. Maaien en afvoeren van het plantaardig materiaal waartussen zich het plastic bevindt, zoals dit in 2019 op Schiermonnikoog, langs de duinenrij is geprobeerd (Figuur 10), is een optie, maar leidt tot veel afval waaruit het plastic vervolgens lastig te scheiden is.

Het verwijderen van de begroeiing heeft bovendien een negatieve invloed op de ontwikkeling van de kwelder. Om het plastic effectief te verwijderen dient het gewas zo kort mogelijk boven het maaiveld te worden afgemaaid Hierdoor ontstaan dus kale plekken op de kwelder, waarvan de hersteltijd sterk seizoensgebonden is. Zolang de kale plakken niet hersteld zijn, zal hier minder sedimentatie 
plaatsvinden, omdat hier geen platen aanwezig zijn die de stroomsnelheid van het water verminderen waardoor sedimentatie van klei of zand kan plaatsvinden (Peralta et al., 2008).

In plaats van de planten te maaien en plantaardig materiaal af te voeren, kan er ook een stofzuiger gebruikt worden om zoveel mogelijk microplastics tussen de planten weg te halen. Dit zal lastiger worden naarmate de begroeiing dichter is. Bij het stofzuigen blijft in principe de ondergrond en de beplanting onaangetast, maar wordt wel losliggend materiaal (de strooisel-laag) verwijderd. Grof plantaardig materiaal kan eventueel nog door zeven van de microplastics worden gescheiden, maar voor het scheiden van microplastics uit de fijne fractie van de strooisel-laag bestaan op dit moment, voor zover ons bekend, nog geen geschikte methoden. In de huidige praktijk zal dan ook, in elk geval de fijne fractie van het opgezogen materiaal noodgedwongen worden afgevoerd naar de vuilverbranding.

Aangezien het meeste plastic in het vloedmerk zal worden afgezet, is het meest effectief om die vers afgezette strooisel-laag te verwijderen. Vooral in het najaar zijn tussen dit materiaal ook veel zaden aanwezig. Daarnaast kunnen er ook verschillende organismen worden aangetroffen (Chang et al., 2016), zoals slakken (Gewoon muizenoortje, Myosotella myosotis), kwelderspringers (Orchestia gammarellus) en meerdere soorten vliegen larven, die leven van het strooisel of van de microorganismen op het strooisel (Schrama et al., 2017). Daarnaast is het strooisel, tijdens afbraak, ook een bron van nutriënten (Schrama et al., 2015). Consistent verwijderen van de strooisel-laag kan dus de voorraad aan zaden aantasten, en plaatselijk het nutriëntenaanbod op de kwelder verminderen. Wanneer verwijderen van strooisel echter alleen incidenteel gebeurt, zoals in het geval van een opruimactie na een incident, dan zal dat geen directe nadelige effecten op de kwelder hebben. Bovendien zal, wanneer tijdig actie wordt ondernomen, het opruimwerk beperkt kunnen blijven tot het gebied rond het vloedmerk. De soorten die daarbij met het strooisel verwijderd worden zijn ook aanwezig in strooisel elders op de kwelder, waardoor de onttrekking van een relatief klein deel waarschijnlijk geen substantieel effect zal hebben op de populatie van die soorten.

Snelle actie is ook zinvol om te voorkomen dat de plastics door wind en springtij hoger op de kwelder terecht komen. Afgezien van het feit dat de plastics dan over een groter oppervlak verspreid liggen, is de begroeiing hoger op de kwelder dichter en de strooisel-laag dikker, waardoor opruimen lastiger wordt. In het broedseizoen wordt dit gebied bovendien gebruikt door broedvogels, waardoor opruimacties in het broedseizoen vermeden zouden moeten worden.

Langer wachten met opruimen zal er ook toe leiden dat een groter deel van de microplastics begraven raken en daardoor nog te verwijderen zijn door de bodem te verstoren. Zolang het niet om extreme hoeveelheden gaat weegt de schade van de aanwezigheid van de pellets in de bodem, waarschijnlijk niet op tegen de schade die het opruimen veroorzaakt.

Elke opruimactie gaat gepaard met op zijn minst intensieve betreding van het terrein en mogelijk de inzet van voertuigen. Betreding van de kwelder zal geen groot probleem zijn omdat de meeste kwelders in Nederlands al flink worden betreden door de koeien en paarden die haar begrazen. Incidentele meer intensieve betreding hoeft geen effect te hebben op de kwelder. Alleen in de pionierszone (op en nabij het wad) kan betreding de pioniersplanten en de bodem te veel beroeren en beschadigen. 

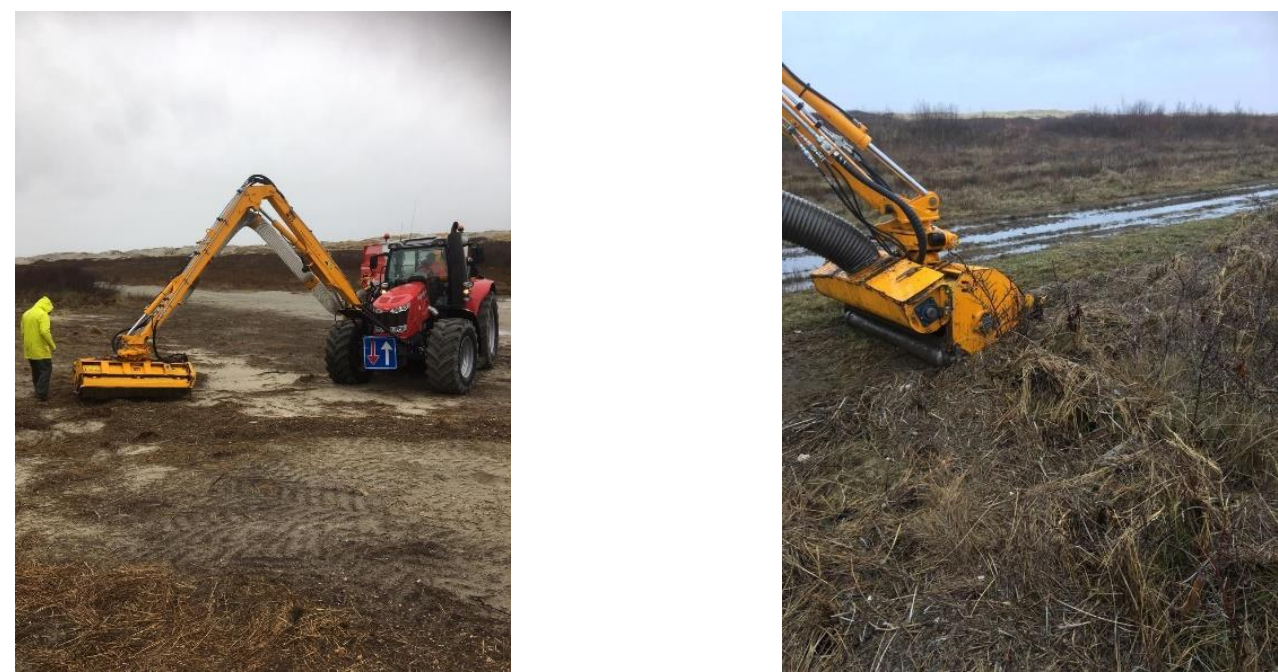

Figuur 10 Inzet van de zuigklepelmaaier langs de duinenrij op Schiermonnikoog (Foto's Jan Willem Zwart, Natuurmonumenten)

\subsection{Harde dijk}

Voor de afwerking van Nederlandse 'harde' zeedijken wordt rond de waterlijn voornamelijk gebruik gemaakt van basaltblokken of asfalt. Een gegoten laag asfalt biedt weinig hechtingsmogelijkheden of onderdak voor organismen. Het opruimen van boven de laagwaterlijn aangespoelde microplastics op dergelijke dijken heeft daarom geen negatieve consequenties voor de lokale ecologie. Door het gladde oppervlak zijn dergelijke dijken bovendien eenvoudig en effectief met 'stofzuigers' schoon te maken. In dijken die zijn opgebouwd uit basaltblokken of breuksteen zijn meer vestigingsplekken voor organismen aanwezig, waarin en waarop zich vooral onder de laagwaterlijn organismen zullen vestigen. Op het daarboven gelegen deel, tussen de laagwaterlijn en hoogwaterlijn, kunnen alleen organismen zich vestigen die zich stevig genoeg aan het oppervlak kunnen hechten en bestand zijn tegen periodiek droogvallen tijdens de laagwater periode. Zeepokken, mossels, oesters, alikruiken en blaasjeswier zijn de typische soorten die hier verwacht kunnen worden. Deze soorten zijn stevig aan de ondergrond verankerd, of kunnen daarvoor zorgen (alikruik) en zullen daarom bij het gebruik van een stofzuiger om plastics op te ruimen niet worden verwijderd. De efficiëntie van het gebruik van de stofzuiger zal negatief worden beïnvloed door de aanwezigheid van zeewier, mossels en oesters als de micro plastics daar tussen en onder terecht komen.

Ook is het vaak niet mogelijk om de plastics die diep tussen de basaltblokken zijn gezakt op te zuigen. Een geïnterviewde merkte op dat een basaltdijk alleen volledig gereinigd kan worden wanneer de stenen worden opgepakt.

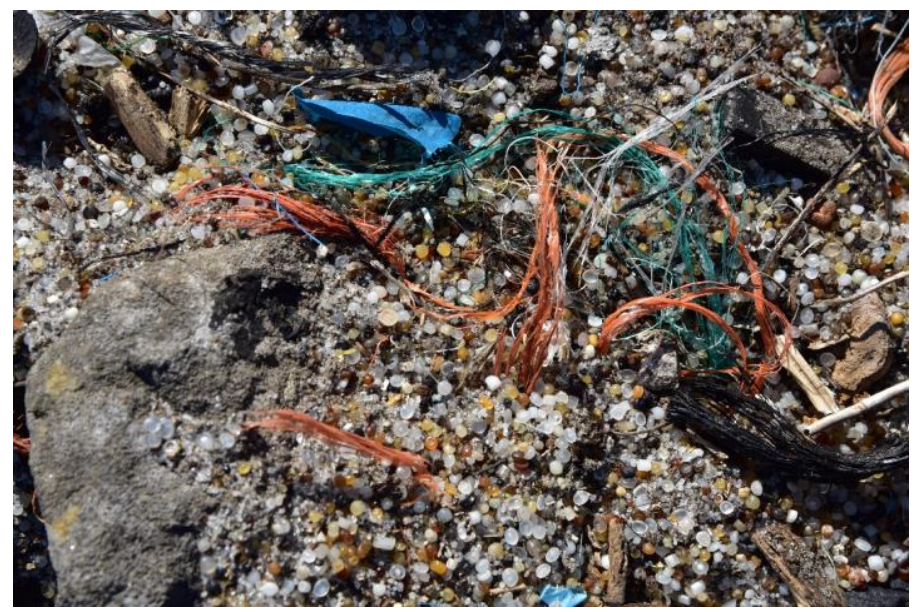

Figuur 11 Op sommige dijkdelen (hier in de haven van Rotterdam) kunnen zich grote hoeveelheden microplastic verzamelen (Foto: HEBO maritiemservice BV). 


\section{Evaluatie opruimmethoden}

In Tabel 1 is een overzicht gegeven van de toepasbaarheid van de verschillende opruimmethoden op basis van de verzamelde gegevens. Er is weinig goed gedocumenteerde informatie beschikbaar over de effectiviteit van de methoden onder verschillende omstandigheden, waardoor de invulling van de tabel inschatting slechts als indicatief moet worden beschouwd. Praktijktesten van de beschikbare methoden onder realistische omstandigheden zijn nodig om betrouwbaarder informatie te verkrijgen.

Uit de evaluatie komt een eenduidig beeld naar voren over de opruimmethoden na maritieme incidenten. Op hoofdlijnen zijn er drie methoden die gebruikt worden om microplastics te verwijderen, te weten opharken, opscheppen of opzuigen, waarna al dan niet een zeef wordt gebruikt om materialen te scheiden.

Opscheppen of opharken zijn geschikte methoden om plastics te ruimen van zachte bodems zonder begroeiing, zoals stranden en eventueel getijdeplaten. Op harde ondergronden, en op vochtig zand is de stofzuiger een effectieve manier om redelijk selectief microplastics te verzamelen, vooral als de pellets nog bovenop het zand liggen. Pellets die in het zand zijn getrapt of gereden, zijn moeilijk op te zuigen. Als het zand droog is, zal er ook veel zand worden opgezogen en is een combinatie met een zeefsysteem aan te bevelen om pellets en zand te scheiden. Voor het effectief werken van de stofzuigmethode is het belangrijk dat wordt vermeden dat grof (plantaardig) materiaal wordt opgezogen omdat dit de opzuigslang snel kan verstoppen.

Stofzuigen kan ook worden toegepast op begroeid terrein, maar naarmate de begroeiing dichter wordt neemt de efficiëntie waarmee microplastics worden verzameld af. Maaien en afvoeren van de begroeiing en het plastic is dan een mogelijkheid, maar dit zal in het groeiseizoen substantiële impact kunnen hebben op het lokale ecosysteem.

De ecologische impact van de andere opruimmethoden wordt ingeschat als maximaal gering, zeker wanneer de duur van de opruimwerkzaamheden en de omvang van het gebied dat geruimd moet worden door snel ingrijpen kan worden beperkt.

De opruimmethoden worden zowel handmatig als gemotoriseerd toegepast. Handmatig harken, scheppen of zeven wordt vooral gebruikt door vrijwilligers om microplastics op bekende hotspots op te ruimen en op deze wijze publieke aandacht voor de chronische verontreiniging met microplastics te genereren. Handmatige methoden kunnen ook praktisch zijn voor het opruimen van microplastics in gebieden waar gebruik van zwaar gemotoriseerd materieel niet mogelijk of wenselijk is. Uiteraard is het oppervlak dat door een persoon handmatig kan worden schoongemaakt beperkt. Voor het opruimen van grotere, goed bereikbare oppervlakken zijn professionele gemotoriseerde systemen beter geschikt. Op droog zand zouden eventueel beach cleaners kunnen worden ingezet die zijn voorzien van fijnere zeven dan wat traditioneel op deze machine wordt toegepast. Op alle andere ondergronden lijkt de stofzuiger methode het meest effectief.

Afhankelijk van de locaties waar gewerkt wordt, zal met de microplastics ook meer of minder ander materiaal worden verzameld, zoals groter zwerfvuil, zand, schelpen en plantaardig materiaal. Het gebruik van zeven werkt goed om plastic pellets te scheiden van droog zand, of droog grof materiaal zoals bijvoorbeeld schelpen of plantaardig materiaal. Wanneer het verzamelde materiaal vochtig is en daardoor aan elkaar klontert, wordt het zeven moeilijker. Waarschijnlijk kan dit opgelost worden door water te gebruiken tijdens het zeven, maar dit is voor zover ons bekend in de praktijk in Nederland nog niet op locatie toegepast. Voor het scheiden van microplastics van plantaardig materiaal van hetzelfde formaat is voor zover ons bekend nog geen geschikte methode gevonden. In de praktijk zal deze fractie van het verzamelde materiaal in het geheel worden afgevoerd.

De hoeveelheid mee verzameld groter zwerfvuil is afhankelijk van de methode. Bij handmatige methoden zullen grotere stukken op het oog kunnen worden verzameld. Wanneer met stofzuigers wordt gewerkt dan is de diameter van de zuigmond bepalend voor de maximale grootte van het zwerfvuil dat mee verzameld kan worden. In de praktijk zal grof materiaal echter zoveel mogelijk worden vermeden omdat hierdoor de zuigslang snel verstopt kan raken. Beach cleaners zijn juist 
ontworpen om, naast zeewier, grover zwerfafval te ruimen van stranden. Door gebruik te maken van fijnere zeven zou het theoretisch mogelijk kunnen zijn om dit grove materiaal samen met de microplastics te verwijderen. Of dit in de praktijk werkt zal moeten worden onderzocht. Overigens zal ook voor het grove materiaal gelden dat plastics lastig op mechanische wijze te scheiden zullen zijn van plantaardig materiaal, zoals zeewier.

Tabel 1 Indicatieve classificatie van de opruimmethoden gebaseerd op de informatie verkregen uit literatuur, interviews en internet. $++=$ geschikt; $+=$ redelijk/mogelijk geschikt; - = ongeschikt. Ontwikkelingsfase $1=$ niet getest; $2=$ prototype getest; $3=$ commercieel beschikbaar; ? = niet bekend; nvt = niet van toepassing, omdat methode voor deze toepassing niet geschikt is.

\begin{tabular}{|c|c|c|c|c|c|c|}
\hline & $\begin{array}{l}\text { Handmatig } \\
\text { harken \& } \\
\text { zeven }\end{array}$ & $\begin{array}{c}\text { scheppen \& } \\
\text { zeven }\end{array}$ & stofzuigen & $\begin{array}{c}\text { Gemotoriseerd } \\
\text { stofzuigen }\end{array}$ & maaien & $\begin{array}{c}\text { zeven } \\
\text { (beach } \\
\text { cleaners) }\end{array}$ \\
\hline \multicolumn{7}{|l|}{ Geschiktheid per ondergrond } \\
\hline Droog zand (strand) & ++ & ++ & + & - & - & + \\
\hline Vochtig zand (strand) & - & + & ++ & ++ & - & - \\
\hline Slib (getijdenplaat) & - & + & - & - & - & - \\
\hline Begroeid terrein (kwelder) & - & - & + & + & ++ & - \\
\hline Hard (dijk) & - & - & ++ & ++ & - & - \\
\hline \multicolumn{7}{|l|}{ Ecologische impact } \\
\hline Strand & nihil & nihil & nihil & gering & nvt & gering \\
\hline Getijdenplaat & nvt & gering & nvt & nvt & nvt & nvt \\
\hline Kwelder & nvt & nvt & gering & gering & ernstig & nvt \\
\hline Dijk & nvt & nvt & nihil & nihil & nvt & nvt \\
\hline \multicolumn{7}{|l|}{ Bediening } \\
\hline Aantal personen & 1 & 1 & 1 & 2 & 1 & 1 \\
\hline \multicolumn{7}{|l|}{ Snelheid ( $m^{2} / 8$ uur/persoon) } \\
\hline Strand & 80 & $?$ & $?$ & $250-500$ & nvt & $\begin{array}{l}\text { onbekend } \\
\text { irt micro's }\end{array}$ \\
\hline Getijdenplaat & nvt & $?$ & nvt & nvt & nvt & nvt \\
\hline Kwelder & nvt & nvt & $?$ & $50-100$ & 100 & nvt \\
\hline Dijk & nvt & nvt & ? & $50-100$ & nvt & nvt \\
\hline \multicolumn{7}{|l|}{ Kosten } \\
\hline Aanschaf apparatuur (euro/stuk) & 150 & $?$ & 250 & $15.000-100.000$ & $?$ & $?$ \\
\hline Huur/inzet (euro/uur) & arbeidsloon & arbeidsloon & arbeidsloon & 300 & $?$ & $?$ \\
\hline $\begin{array}{l}\text { Status ontwikkeling } \\
\text { Ontwikkelingsfase }\end{array}$ & 3 & 2 & 3 & 3 & 3 & 1 \\
\hline
\end{tabular}




\section{Opruimen op het water}

De voorgaande hoofdstukken betroffen het opruimen van op het land aangespoelde microplastics. In sommige situaties is het wellicht mogelijk om eerder met opruimen te beginnen: terwijl de plastics zich nog op het water bevinden. In het geval van een olie lozing is dit de geprefereerde strategie, juist omdat gestrande olie voor veel overlast zorgt en moeilijk is op te ruimen. Op verschillende locaties in Nederland is materiaal aanwezig dat kan worden ingezet om drijvende olie op te ruimen en verspreiding te voorkomen. Deze olie-skimmers en oliekerende schermen kunnen wellicht ook worden ingezet in respons op een geconcentreerde lozing van drijvende microplastics. Tijdens

oliebestrijdingsoefeningen bleek dit materieel in elk geval effectief in het vasthouden en verwijderen van drijvende popcorn dat werd gebruikt om een olievlek te simuleren (pers. mededeling Jean Groels, RWS).

Een belangrijke randvoorwaarde voor deze aanpak is dat de op zee drijvende plastics gesignaleerd worden voordat zij over een groot oppervlak verspreid zijn geraakt. Dit signaleren zal bij microplastics lastiger zijn dan bij olie waarvan een vlek vanuit de lucht vaak duidelijk zichtbaar is.

Mogelijk kunnen oliekerende schermen wel worden ingezet om kwetsbare en moeilijk te reinigen gebieden af te schermen tegen drijvende microplastics. Dit zou preventief kunnen gebeuren als, op basis van wind en stroming, kan worden aangenomen dat verloren microplastis deze gebieden zullen kunnen bereiken. Ook zou door het plaatsten van de schermen verder verontreiniging kunnen worden voorkomen van een gebied waar kort na het incident de eerste plastics zijn aangespoeld. Oliekerende schermen liggen opgeslagen op een aantal strategische locaties langs de kust zoals in Harlingen en Rotterdam. Ze hebben een lengte van ca. $200 \mathrm{~m}$ en zijn onderling koppelbaar. Door de hoogte van 1 tot 2 meter werken ze ook bij enige golfslag. 


\section{Conclusies en aanbevelingen}

\subsection{Meest effectieve opruimtechniek}

Stofzuigen lijkt de meest geschikte methode om aangespoelde microplastics op te ruimen van verschillende ondergronden. Op zand is het dan wel belangrijk dat de plastic korrels nog op de ondergrond liggen, en er dus niet door betreding in zijn weggedrukt. Op begroeid terrein en niet geasfalteerde dijken zal de opruim efficiëntie lager zijn dan op vlakke vochtige stranden of geasfalteerde dijken. Afhankelijk van de ondergrond wordt meer of minder ander materiaal zoals zand en plantenresten opgezogen. Middels zeven kunnen grootte fracties gescheiden worden. Binnen de fractie waar zich het meeste microplastic bevindt, kan eventueel door gebruik te maken van verschil in drijfvermogen nog een verdere scheiding worden aangebracht. Het grootschalig verder scheiden van microplastics en plantenresten binnen een groottefractie is op dit moment nog niet mogelijk. Het zoveel mogelijk scheiden van het materiaal tijdens het opruimen heeft als voordeel dat er minder afval hoeft te worden opgeslagen/afgevoerd en dat natuurlijk materiaal in het gebied kan worden achtergelaten. Als deze scheiding echter alleen plaats kan vinden op een andere locatie dan is de meerwaarde waarschijnlijk gering.

\subsection{Ecologische effecten van opruimen}

Ecologische effecten van pellets zijn onduidelijk en mogelijk te subtiel om onder veldcondities waar te nemen, maar alleen al vanuit ethisch en esthetisch oogpunt zal verloren afval altijd zoveel mogelijk opgeruimd moeten worden.

Het is onvermijdelijk dat er bij de opruimacties organismen worden beschadigd of verwijderd.

Wanneer deze echter in een beperkt gebied plaatsvinden dan is snel herstel vanuit omliggend terrein mogelijk.

Hierbij is het wel van belang dat de structuur van de ondergrond niet door de opruimacties wordt veranderd. Op harde ondergrond en zandstranden zal dit niet het geval zijn, maar op kwelders is het bijvoorbeeld verstandig om niet rigoureus te maaien om de laatste pellets te verwijderen. Dit herstel zal pas beginnen nadat de opruimwerkzaamheden zijn gestaakt, waardoor het belangrijk is dat na een incident een strategie wordt gekozen waardoor naast omvang ook de tijdsduur zoveel mogelijk wordt beperkt (zie 7.3).

Omdat maritieme incidenten, waarbij microplastics worden verloren, gelukkig niet met regelmaat in het hetzelfde gebied plaatsvinden, zullen ook opruimacties incidenteel worden uitgevoerd, waardoor het ecosysteem tijd krijgt om te herstellen.

\subsection{Opruim en respons strategie}

Snel handelen na een maritiem incident waarbij veel plastic microplastics zijn vrijgekomen is belangrijk. Om verschillende redenen wordt het opruimen van aangespoelde microplastics moeilijker naarmate er meer tijd verstrijkt, en zal ook de ecologische impact toenemen. Het plastic wordt initieel afgezet op het vloedmerk en zal in de tijd door getijdebewegingen en wind verspreid worden over een groter gebied.

Niet snel opgeruimde plastics zullen op stranden begraven raken onder stuifzand, en in het zand worden gedrukt door wandelaars en voertuigen waardoor opruimen met behulp van een stofzuiger niet goed meer mogelijk is.

Op een kwelder afgezette plastics kan na verloop van tijd ook de hoger gelegen delen bereiken waar de dichtere beplanting het opruimen bemoeilijkt. De hoger gelegen gebieden op een kwelder, en in minder mate op stranden worden bovendien gebruikt door nestelende vogels, zodat opruimakties daar in het broedseizoen zijn af te raden. 
De beste opruimstrategie lijkt daarom om zo snel mogelijk na het incident te beginnen met het opruimen van het vloedmerk, bij voorkeur na elke hoogwater periode. Stranden zouden kunnen worden afgeschermd voor wandelaars en jutters om te voorkomen dat de plastics in het zand worden gedrukt. Bij een incident voor de kust zal het geen weken duren voordat de grootste hoeveelheid microplastics is aangespoeld. Verspreidingsmodellen schatten bijvoorbeeld dat binnen 3 weken na het incident met MSC Zoe de meeste pellets ergens waren aangespoeld (Foekema et al., 2021). Gedurende deze 'aanspoelperiode' kan naast het met regelmaat schonen van de vloedlijn, ook getracht worden om moeilijk opruimbare gebieden, zoals kwelders, te beschermen tegen binnendrijvend plastic bijvoorbeeld door gebruik te maken van oliekerende schermen.

Om de ideale snelle respons mogelijk te maken is het nodig dat opruimmiddelen stand-by in het land beschikbaar zijn en snel naar de juiste plaats getransporteerd kunnen worden.

\subsection{Samenwerking}

Bij het verzamelen van de gegevens viel het op dat er weinig samenwerking bestaat rond het opruimen van microplastics, en dat elk incident min of meer lokaal wordt afgehandeld. Zelfs binnen Nederland lijkt er weinig communicatie te zijn tussen de professionele partijen die zich met het opruimen van microplastics bezig houden. Voor geen van deze partijen is dit overigens corebusiness en verdere ontwikkeling van mogelijk efficiëntere methoden om microplastics te ruimen vindt niet plaats omdat er weinig marktperspectief lijkt te zijn. Op verschillende plaatsen werd hetzelfde wiel uitgevonden, en dezelfde knelpunten geconstateerd.

Het uitwisselen van kennis en ervaring binnen Nederland en eventueel Europa op het gebied van opruimen van microplastics kan worden bevorderd. Wanneer in dit kader verschillende prototypen kunnen worden getest, wordt ook een beter beeld verkregen van de werkelijke effectiviteit. RWS zou kunnen overwegen een dergelijke samenwerking te organiseren, zeker als dit ook enig marktperspectief kan bieden aan de verschillende partijen.

\subsection{Kennishiaten}

De beschrijvingen van de effectiviteit van de verschillende opruimmethoden op verschillende ondergronden in deze inventarisatie is gebaseerd op opgaves van de bouwers en gebruikers van de systemen en soms op waarnemingen van derden. Voor een objectieve beoordeling zijn gerichte proeven nodig.

Het scheiden van microplastic en met name plantaardig materiaal van dezelfde grootte is op dit moment nog niet effectief mogelijk. Ontwikkelaars geven aan wel ideeën te hebben hoe dit zou kunnen, maar zijn terughoudend om deze in dit stadium te delen. Hierdoor blijft ook onduidelijk hoe effectief praktijktesten van dergelijke ideeën zijn.

Dicht begroeide kwelders en slibbige getijdenplaten zijn moeilijk schoon te maken zonder substantiële impact op het lokale systeem. Idealiter wordt verontreiniging van deze gebieden voorkomen door de plastics vroegtijdig op het water op te vangen. Dit zou kunnen door het inzetten van oliekerende schermen. Een probleem hierbij is dat (drijvende) microplastics op zee nog lastig te lokaliseren zijn. Wellicht kan een lokalisatietechniek vanuit de lucht worden ontwikkeld waardoor het ruimen op zee beter mogelijk zal worden, zeker in combinatie met stromingsmodellen die voorspellen waar de meeste microplastics waarschijnlijk zullen stranden.

Als er toch microplastics in kwelders en op slibbige getijdenplaten terechtkomen is 'niets doen' wellicht de beste optie, omdat de impact van de aanwezigheid van plastic pellets op het ecosysteem gering lijkt. Zonder gericht onderzoek blijft dit echter een aanname. Langer lopend onderzoek naar de effecten van plastic pellets op dergelijke gebieden en op het daarmee samenhangende deel van het ecosysteem (foeragerende vogels) om deze aanname te toetsen is zinvol. 


\section{Dankwoord}

Een belangrijk deel van de in dit rapport beschreven informatie is verkregen via interviews met de volgende personen: Henk Middendorp en Jean Groels (beiden RWS), Anna Wegner (Waterschap Rijn en IJssel), Ivo Pallemans en Tom van Vooren (beiden Envisan), Stefan van 't Land (HEBO), Andre Borsch (DBS Harlingen), Josh Beech (Nurdle.org), Eric de Vries (Bende van Strand), Jan Willem Zwart (Natuurmonumenten). Wij danken hen hartelijk voor het belangeloos delen van hun informatie, inzichten, gedachten en meningen. Rune Bergstrøm (Norwegian Coastal Administration) en AnneSophie Lapointe (HoolaOne) leverden waardevolle informatie via email. 


\section{Kwaliteitsborging}

Wageningen Marine Research beschikt over een ISO 9001:2015 gecertificeerd kwaliteitsmanagementsysteem. Dit certificaat is geldig tot 15 december 2021. De organisatie is gecertificeerd sinds 27 februari 2001. De certificering is uitgevoerd door DNV GL. 


\section{Literatuur}

Boitsov, S., Knutsen, H., Simonsen, J.H., Frantzen, S., 2020. Undersøkelse av mageinnhold i fiskeyngel og kystnære fiskearter etter utslippet av plastpellets fra M/V Trans Carrier - Studies of stomach contents in juvenile and coastal fish species after discharge of plastic pellets from M/V Trans Carrier. Havforskningsinstituttet, Bergen, Norway, pp 17

Carpenter, E.J., Anderson, S.J., Harvey, G.R., Miklas, H.P., Peck, B.B., 1972. Polystyrene Spherules in Coastal Waters. Science 178: 749-750 doi http://dx.doi.org/10.1126/science.178.4062.749

Chang, A.E.R., Veeneklaas R.M., Bakker J.P., 2016. Seed Dynamics Linked to Variability in Movement of Tidal Water Stable URL: http://www.jstor.org/stable/4499221

Christianen M.J.A., Holthuijsen S.J. , van der Zee E.M., van der Eijk A., Govers L.L., van der Heide T., de Paoli H., Olff H., 2015. Ecotopen- en Kansrijkdomkaart van de Nederlandse Waddenzee.

Waddensleutels rapportnummer 2015.04.01. DOI: 10.13140/RG.2.1.4145.4243

Day, R.H., 1980. The occurrence and characteristics of plastic pollution in Alaska's marine birds. Master thesis. University of Alaska, Fairbanks, pp 120

de Carvalho-Souza, G.F., Llope, M., Tinôco, M.S., Medeiros, D.V., Maia-Nogueira, R., Sampaio, C.L.S., 2018. Marine litter disrupts ecological processes in reef systems. Marine Pollution Bulletin 133: 464-471 doi https://doi.org/10.1016/j.marpolbul.2018.05.049

Dolva, H., Solem Holt, H., Henriksen, T., Nordaas, S., 2020. Erfaringer fra plastpelletsaksjonen Trans Carrier, med fokus på rensemetoder på strand - Experiences from the plastic pellets pollution incident from Trans Carrier, with focus on shoreline clean-up operations. Kustverket - Norwegian Coastal Administration, Ålesund, Norway, pp 36

Ebbesmeyer, C.C., Ingraham, J., W. James, 1992. Shoe spill in the North Pacific. Eos, Transactions American Geophysical Union 73: 361-365 doi https://doi.org/10.1029/91EO10273

Ebbesmeyer, C.C., Ingraham, W.J., Royer, T.C., Grosch, C.E., 2007. Tub toys orbit the Pacific subarctic gyre. Eos, Transactions American Geophysical Union 88: 1-4

Foekema, E., van der Molen, J., Asjes, A., Bijleveld, A., Brasseur, S., Camphuysen, K., van Franeker, J.A., Holthuijsen, S., Kentie, R., Kühn, S., Leopold, M., Kleine Schaars, L., Lok, T., Niemann, H., Schop, J., 2021. Ecologische effecten van het ongeluk met de MSC Zoe op het Nederlandse Waddengebied, met focus op microplastics. NIOZ Rapport 2021-03. NIOZ Royal Netherlands Institute for Sea Research, 't Horntje, Texel, The Netherlands. 99pp. DOI: 10.25850/nioz/7b.b.mb

Galafassi, S., Nizzetto, L., Volta, P., 2019. Plastic sources: A survey across scientific and grey literature for their inventory and relative contribution to microplastics pollution in natural environments, with an emphasis on surface water. Science of The Total Environment 693: 133499 doi https://doi.org/10.1016/j.scitotenv.2019.07.305

Harper, P.C., Fowler, J.A., 1987. Plastic pellets in New Zealand Storm-killed Prions. Notornis 34: 65-70

Haseler, M., Schernewski, G., Balciunas, A., Sabaliauskaite, V., 2018. Monitoring methods for large microand meso-litter and applications at Baltic beaches. Journal of Coastal Conservation 22: 27-50 doi https://doi.org/10.1007/s11852-017-0497-5

Haseler, M., Weder, C., Buschbeck, L., Wesnigk, S., Schernewski, G., 2019. Cost-effective monitoring of large micro- and meso-litter in tidal and flood accumulation zones at south-western Baltic Sea beaches. Marine Pollution Bulletin 149: 110544 doi https://doi.org/10.1016/j.marpolbul.2019.110544

Haseler, M., Balciunas, A., Hauk, R., Sabaliauskaite, V., Chubarenko, I., Ershova, A., Schernewski, G., 2020. Marine Litter Pollution in Baltic Sea Beaches - Application of the Sand Rake Method. Frontiers in Environmental Science 8 doi https://doi.org/10.3389/fenvs.2020.599978

Janssen G. \& Mulder S., 2005. Zonation of macrofauna across sandy beaches and surf zones along the Dutch coast. OCEANOLOGIA, 47 (2), 2005. pp. 1-18

Janssen G., Kleef H., Mulder S. \& Tydeman P., 2008. Pilot assessment of depth related distribution of macrofauna in surf zone along Dutch coast and its implications for coastal management. Marine Ecology 29 (Suppl. 1) (2008) 186-194

Koelmans, A.A., Besseling, E., Wegner, A., Foekema, E.M., 2013a. Plastic as a Carrier of POPs to Aquatic Organisms: A Model Analysis. Environmental Science \& Technology 47, 7812-7820 
Koelmans, A.A., Besseling, E., Wegner, A., Foekema, E.M., 2013b. Plastic As a Carrier of POPs to Aquatic Organisms: A Model Analysis (vol 47, pg 7812, 2013). Environmental Science \& Technology 47, 89928993

Peralta, G., van Duren L., Morris, E., Bouma, T. 2008. Consequences of shoot density and stiffness for ecosystem engineering by benthic macrophytes in flow dominated areas: a hydrodynamic flume study. Marine Ecology Progress Series 368:103-115

Kartar, S., Abou-Seedo, F., Sainsbury, M., 1976. Polystyrene waste in the Seventh Estuary: A progress report. Marine Pollution Bulletin 4: 144 doi https://doi.org/10.1016/0025-326X(76)90092-8

Kühn, S., Van Franeker, J.A., 2020. Quantitative overview of marine debris ingested by marine megafauna. Marine Pollution Bulletin 151: 110858 doi https://doi.org/10.1016/j.marpolbul.2019.110858

Kühn, S., Meijboom, A., Bittner, O., Van Franeker, J.A., 2021. Fulmar Litter Threshold Value Monitoring in the Netherlands - Update 2020. Wageningen Marine Research, Den Helder, The Netherlands, pp 64 doi https://doi.org/10.18174/553736

Llewellyn, P.J., Shackley, S.E., 1996. The effects of mechanical beachcleaning on invertabrate populations. British wildlife 7: 147-155

Lloret, J., Pedrosa-Pamies R., Vandal N., Rorty R., Ritchie M., McGuire C., Chenoweth K., Valiela I., 2021. Salt marsh sediments act as sinks for microplastics and reveal effects of current and historical land use changes. Environmental Advances 4:100060

Mouat, J., Lozano, R.L., Bateson, H., 2010. Economic Impacts of Marine Litter. KIMO International, pp. 105

Ogi, H., 1990. Ingestion of plastic particles by sooty and short-tailed shearwaters in the North Pacific.

Shomura R.S., Godfrey M.L., Proceedings of the Second International Conference on marine debris, Honolulu, Hawaii, pp 635-652

Philippart, K., Hanssen, L., van Dijk, J., 2019. Wat zijn de gevolgen van de door de MSC Zoe verloren lading voor de Noordzeekustzone en de Waddenzee? Onderzoeks- en monitoringplan voor de korte- en langetermijngevolgen van microplastics voor het Waddengebied en haar bewoners. Waddenacademie, Leeuwarden, The Netherlands

PlasticsEurope, 2020. Plastics - the Facts 2020. An analysis of European latest plastics production, demand and waste data. PlasticsEurope - Association of Plastics Manufacturers, Brussels, Belgium, pp 64 doi https://www.plasticseurope.org/en/resources/publications/4312-plastics-facts-2020

Rijkswaterstaat, 2021. https://www.rijkswaterstaat.nl/nieuws/archief/2021/01/overeenstemmingschadeafhandeling-met-reder-msc-zoe. Bezocht 26112021.

Ryan, P.G., 1988. Effects of ingested plastic on seabird feeding: evidence from chickens. Marine Pollution Bulletin 19: 125-128 doi https://doi.org/10.1016/0025-326X(88)90708-4

Schlacher, T.A., Thompson, L., Price, S., 2007. Vehicles versus conservation of invertebrates on sandy beaches: mortalities inflicted by offroad vehicles on gost crabs. Marine Ecology 28: 354-367

Schrama, M., van Boheemen L.A., Olff H., Berg M.P., 2015. How the litter-feeding bioturbator Orchestia gammarellus promotes late-successional saltmarsh vegetation. Journal of Ecology 103:915-924

Schrama, M., van der Plas F., Berg M.P., Olff, H. 2017. Decoupled diversity dynamics in green and brown webs during primary succession in a saltmarsh. Journal of Animal Ecology 86:158-169.

Tanaka, K., Yamashita, R., Takada, H., 2018. Transfer of Hazardous Chemicals from Ingested Plastics to Higher-Trophic-Level Organisms. The Handbook of Environmental Chemistry Springer, Berlin, Heidelberg. doi https://doi.org/10.1007/698_2018_255

Tanaka, K., Watanuki, Y., Takada, H., Ishizuka, M., Yamashita, R., Kazama, M., Hiki, N., Kashiwada, F., Mizukawa, K., Mizukawa, H., Hyrenbach, D., Hester, M., Ikenaka, Y., Nakayama, S.M.M., 2020. In vivo Accumulation of Plastic-Derived Chemicals into Seabird Tissues. Current Biology 30: 723-728 doi http://dx.doi.org/10.1016/j.cub.2019.12.037

Turner, A., Williams, T., Pitchford, T., 2021. Transport, weathering and pollution of plastic from container losses at sea: Observations from a spillage of inkjet cartridges in the North Atlantic Ocean. Environmental Pollution 284: 117131 doi https://doi.org/10.1016/j.envpol.2021.117131

UNEP, 2011. UNEP Year Book, 2011. Emerging issues in our global environment, United Nations Environmental programme, Nairobi, pp 79pp

Vader W., 1969. Verspreiding en biologie van haustorius arenarius, de zandvlokreeft, in Nederland (crustacea, amphipoda). Mededeling nr. 65 van het Delta Instituut voor Hydrobiologisch Onderzoek, Yerseke

Van Franeker, J.A., 1983. Plastics - een bedreiging voor zeevogels. Nieuwsbrief NSO 14: 41-61 
Van Franeker J. A., Bravo Rebolledo E. L., Hesse E., IJsseldijk L. L., Kühn S., Leopold M., Mielke L. 2018. Plastic ingestion by harbour porpoises Phocoena phocoena in the Netherlands: Establishing a standardised method. Ambio . 2018 May;47(4):387-397. doi: 10.1007/s13280-017-1002-y.

Vanermen N., Stienen E.W.M., De Meulenaer B., Van Ginderdeuren K. \& Degraer S., 2009. Low dietary importance of polychaetes in opportunistic feeding Sanderlings Calidris alba on Belgian beaches. Ardea 97: 81-87

Viehman, S., Vander Pluym J.L., Schellinger, J. 2011. Characterization of marine debris in North Carolina salt marshes. Marine Pollution Bulletin 62:2771-2779.

WSC, 2020. Containers Lost at Sea - 2020 Update. World Shipping Council (WSC), Washington, DC, USA, pp 4. https://safety4sea.com/wp-content/uploads/2020/2007/WSC-Containers-Lost-at-Sea2020_2007.pdf

Zelinski, S., Botero C.M., Yanes, A. 2019. To clean or not to clean? A critical review of beach cleaning methods and impacts Marine Pollution Bulletin, Volume 139, Pages 390-401.

https://doi.org/10.1016/j.marpolbul.2018.12.027 


\section{Verantwoording}

Rapport C095/21

Projectnummer: 4315100181

Dit rapport is met grote zorgvuldigheid tot stand gekomen. De wetenschappelijke kwaliteit is intern getoetst door een collega-onderzoeker en het verantwoordelijk lid van het managementteam van Wageningen Marine Research

Akkoord:

Dr. Ruud Jongbloed

Senior onderzoeker

Handtekening:

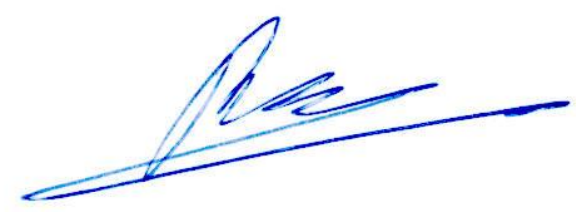

Datum:

30 november 2021

Akkoord:

Drs. J. Asjes

Manager Integratie

Handtekening:

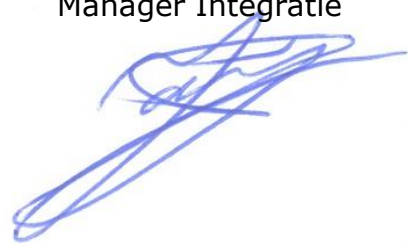

Datum:

30 november 2021 
Wageningen Marine Research

T: $+31(0) 317487000$

E: marine-research@wur.nl

www.wur. $\mathrm{nl} /$ marine-research

Bezoekers adres:

- Ankerpark 271781 AG Den Helder

- Korringaweg 7, 4401 NT Yerseke

- Haringkade 1, 1976 CP IJmuiden
Wageningen Marine Research levert met kennis, onafhankelijk wetenschappelijk onderzoek en advies een wezenlijke bijdrage aan een duurzamer, zorgvuldiger beheer, gebruik en bescherming van de natuurlijke rijkdommen in zee-, kust- en zoetwatergebieden.
Wageningen Marine Research is onderdeel van Wageningen University \& Research. Wageningen University \& Research is het samenwerkingsverband tussen Wageningen University en Stichting Wageningen Research en heeft als missie: 'To explore the potential of nature to improve the quality of life' 